\title{
QUEEN'S
UNIVERSITY
BELFAST
}

\section{Exploring molecular recognition pathways within a family of gelators with different hydrogen bonding motifs}

Hardy, J. G., Hirst, A. R., Ashworth, I., Brennan, C., \& Smith, D. K. (2007). Exploring molecular recognition pathways within a family of gelators with different hydrogen bonding motifs. Tetrahedron, 63(31), 7397-7406. https://doi.org/10.1016/j.tet.2007.03.120

\section{Published in:}

Tetrahedron

\section{Document Version:}

Peer reviewed version

Queen's University Belfast - Research Portal:

Link to publication record in Queen's University Belfast Research Portal

\section{Publisher rights}

Copyright ( 2007 Elsevier Ltd.

This manuscript version is made available under the CC-BY-NC-ND 4.0 license http://creativecommons.org/licenses/by-nc-nd/4.0/), which permits distribution and reproduction for non-commercial purposes, provided the author and source are cited.

\section{General rights}

Copyright for the publications made accessible via the Queen's University Belfast Research Portal is retained by the author(s) and / or other copyright owners and it is a condition of accessing these publications that users recognise and abide by the legal requirements associated with these rights.

Take down policy

The Research Portal is Queen's institutional repository that provides access to Queen's research output. Every effort has been made to ensure that content in the Research Portal does not infringe any person's rights, or applicable UK laws. If you discover content in the Research Portal that you believe breaches copyright or violates any law, please contact openaccess@qub.ac.uk. 
Exploring molecular recognition pathways within a family of gelators with different hydrogen bonding motifs

John G. Hardy ${ }^{\mathrm{a}}$, Andrew R. Hirst ${ }^{\mathrm{a}}$, Ian Ashworth ${ }^{\mathrm{b}}$, Colin Brennan ${ }^{\mathrm{b}}$, David K. Smith ${ }^{\mathrm{a},}$

\section{Abstract}

We report the synthesis of a family of gelators in which alkyl chains are connected to the amino groups of L-lysine methyl ester using a range of different hydrogen bonding linking groups (carbamate, amide, urea, thiourea and diacylhydrazine) using simple synthetic methodology based on isocyanate or acid chloride chemistry. The ability of these compounds to gelate organic solvents such as toluene or cyclohexane can be directly related to the ability of the linking group to form intermolecular hydrogen bonds. In general terms, the ability to structure solvents can be considered as: thiourea<carbamate<amide<urea diacylhydrazine. This process has been confirmed by thermal measurements, scanning electron microscopy (SEM) and infrared and circular dichroism spectroscopies. By deprotecting the methyl ester group, we have demonstrated that a balance between hydrophobic and hydrophilic groups is essential-if the system has too much hydrophilicity (e.g., diacylhydrazine, urea) it will not form gels due to low solubility in the organic media. However, the less effective gelators based on amide and carbamate linkages are enhanced by converting the methyl ester to a carboxylic acid. Furthermore, subsequent mixing of the acid with a second component (diaminododecane) further enhances the ability to form networks, and, in the case of the amide, generates a two-component gel, which can immobilise a wide range of solvents of industrial interest including petrol and diesel (fuel oils), olive oil and sunflower oil (renewable food oils) and ethyl laurate, isopropyl myristate and isopropyl palmitate (oils used in pharmaceutical formulation). The gels are all thermoreversible, and may therefore be useful in controlled release/formulation applications.

\section{Introduction}

The ability of simple organic molecules to self-assemble into structures with nanoscale dimensions is an exciting frontier of chemical science. ${ }^{1,1 a}$ and $1 b$ Perhaps one of the most widespread phenomena, which can be understood in these terms is the gelation of solvent media by small amounts of low molecular weight additives. ${ }^{2}$ 2a, $2 \mathrm{~b}$ and $2 c$ Gelation occurs when individual molecular building blocks 
assemble in a directional manner to yield a network structure. Most gel-phase materials are underpinned by fibrillar assemblies, reminiscent of the amyloid fibril structures in which defective proteins assemble in neurodegenerative disorders such as Alzheimer's disease. ${ }^{3}$ The individual molecular building blocks are held together by multiple non-covalent interactions, ${ }^{4}$ with hydrogen bonds, $\pi-\pi$ interactions and the hydrophobic effect all having been shown to play important roles. A wide range of different types of organic molecule have been investigated as gelators, with the most widely explored being saccharides, ${ }^{5}$ peptides and ureas, ${ }^{6}$ nucleobases ${ }^{7}$ and steroid derivatives. ${ }^{8}$

The soft gel-phase materials, which are assembled from synthetic building blocks have a wide range of proposed and actual applications in materials and biological chemistry. For example, it has been demonstrated that the assembled organic network can be used to template the synthesis of functional inorganic nanostructures. 9 , 9a, 9b, 9c, 9d and 9e Soft gel-phase materials also have great potential in drug delivery. ${ }^{10,10 a, 10 b, 10 \mathrm{c} \text { and } 10 \mathrm{~d}}$ Recently, their potential in tissue engineering was also demonstrated by the use of a peptide hydrogel to support the re-growth of cells in the optic nerve of a blind hamsterrestoring vision. ${ }^{11}$

Understanding the non-covalent interactions, which underpin the hierarchical assembly process of gelation is a challenging task. It is widely accepted that individual molecules can assemble into oligomers as a consequence of molecular recognition interactions between the building blocks. These oligomers subsequently grow to form fibrils by the same process. In many cases, the fibrils then bundle together to form fibres. These fibres subsequently form an extended network, which is capable of supporting the gel. ${ }^{12}$ It is worth noting that the bulk solvent is immobilised as a consequence of capillary forces, with individual solvent molecules actually retaining their mobility within the gel on the molecular scale. ${ }^{13,13 a}$ and $13 b$

In order to understand the molecular recognition pathways, which underpin gelation, we have previously explored a range of dendritic, peptide-based architectures, constructed using L-lysine building blocks. ${ }^{14}$ In general, we have investigated dumbbell shaped, bola-amphiphile-type structures in which peptidic 'head groups' are attached to either end of an aliphatic diamine spacer chain either via covalent or non-covalent interactions. ${ }^{15,15 a, 15 b \text { and } 15 \mathrm{c}}$ These molecules self-assemble to form gels as a consequence of intermolecular hydrogen bond interactions between peptide head groups. We have reported the effect of spacer chain, ${ }^{13 a}$ dendritic generation, ${ }^{16}$ chirality, ${ }^{17}$ solvent ${ }^{18}$ and molar composition $^{19,19 a \text { and } 19 b}$ on the gelation process.

There is a wealth of literature describing supramolecular gels comprised of amino acid hydrogen bonding moieties functionalised with long alkyl chains. ${ }^{20}, 20 \mathrm{a}, 20 \mathrm{~b}, 20 \mathrm{c}, 20 \mathrm{~d}, 20 \mathrm{e}, 20 \mathrm{f}, 20 \mathrm{~g}, 20 \mathrm{~h}, 20 \mathrm{i}, 20 \mathrm{j}, 20 \mathrm{k}, 20 \mathrm{l}, 20 \mathrm{~m}, 20 \mathrm{n}$, 200, 20p, 20q, 20r and 20s Of particular relevance here, the Hanabusa group have reported L-lysine based organogelators where the amines of lysine have been functionalised with long chain fatty acids. They have also found that minor modifications to this structure can yield potent hydrogelators. In the 
search for gelators built from biocompatible subunits, we became interested in L-lysine derivatives in which the surface groups were functionalised with long chain fatty acids. In a preliminary communication, we reported the ability of these structures to form gels in their own right, as well as in combination with aliphatic diamines. ${ }^{21}$ Subsequently, we became interested in the precise role of the hydrogen bonding groups. Although there has been considerable research exploring amides and ureas, $^{6}$ there has been little direct comparison of subtly different hydrogen bonding motifs. We therefore decided to target the synthesis of molecules in which the alkyl chains were grafted to Llysine using different hydrogen bonding motifs (amide, urea, thiourea, carbamate and diacylhydrazine). By investigating the gelation potential of these molecules, we hoped to gain a deeper insight into the molecular recognition pathways which underpin gelation. The results of these studies are the subject of this paper.

\section{Results and discussion}

\subsection{Synthesis of the gelators}

Compound 1-amide was synthesised using standard amide coupling methodology (Scheme 1). Dodecanoyl chloride was reacted with lysine methyl ester in the presence of triethylamine to provide 1 -amide in good yield. Deprotection of the methyl ester was achieved by saponification with aqueous $\mathrm{NaOH}$ in methanol to give 2-amide. It should be noted that compound 2-amide has previously been reported by the Hanabusa group. ${ }^{22}$ 


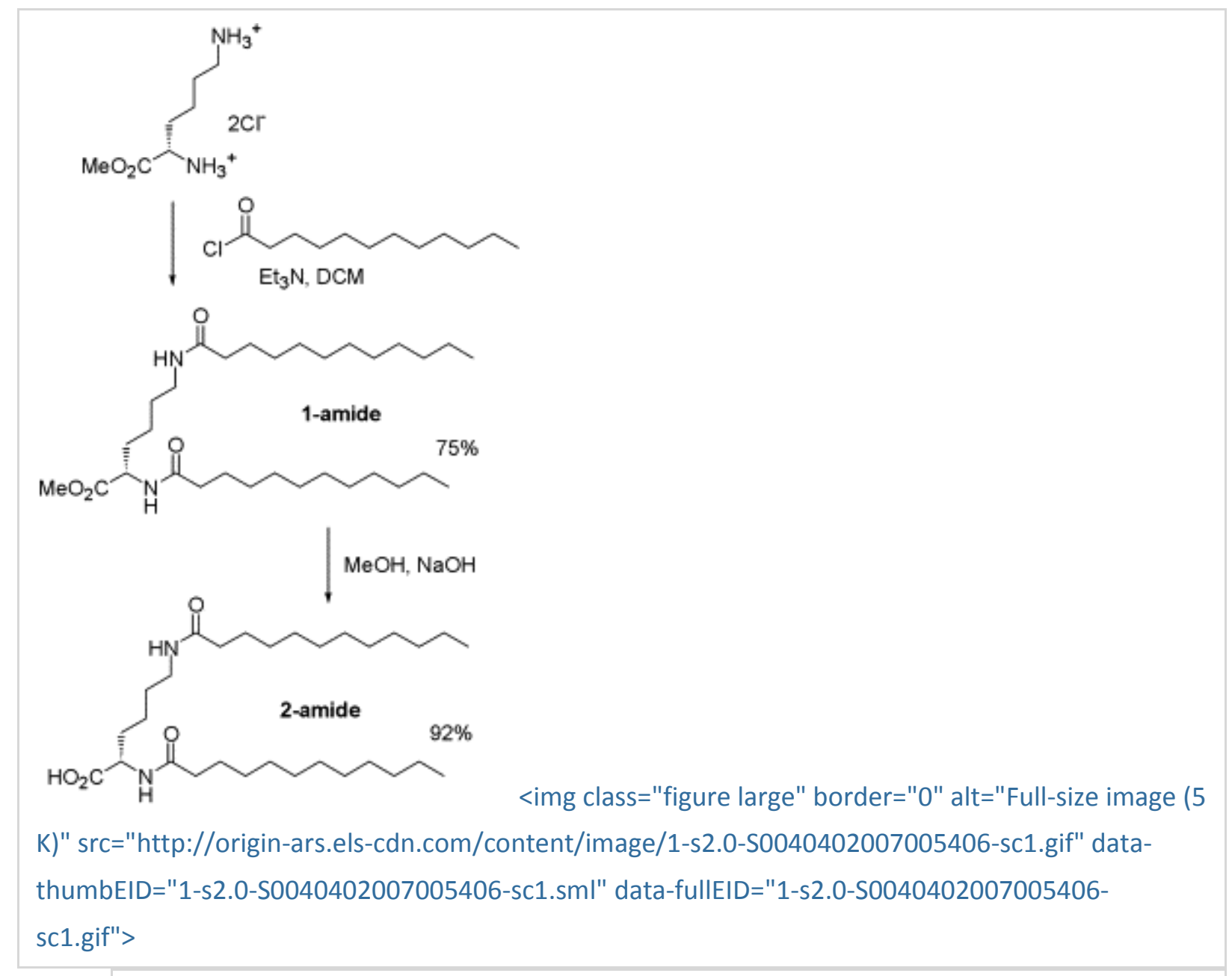

Scheme 1.

Synthesis of 1-amide and 2-amide.

Figure options

Download full-size imageDownload as PowerPoint slideln order to investigate related gelators, with different hydrogen bonding units, we needed a simple synthetic approach for coupling functional groups onto lysine. A number of research teams have employed isocyanates to great effect in the synthesis of gelation systems. ${ }^{23,23 a,}$ 23b, 23c and 23d This reaction is even sometimes sufficiently efficient to give rise to gelation in situ without reaction workup. Given the simplicity of isocyanate methodology, we therefore decided to use this approach to synthesise carbamate, urea and diacylhydrazine analogues. L-Lysine diisocyanate is commercially available and this approach provides the target materials in very good yields (Scheme 2). We reacted L-Iysine diisocyanate (LDI) with dodecanol in refluxing toluene to yield 1carbamate. Saponification of the ester provided 2-carbamate in good yield. Lysine diisocyanate was then reacted with either aminododecane or dodecanoichydrazine to provide 1-urea and 1-diacylhydrazine, respectively, in quantitative yields. Once 


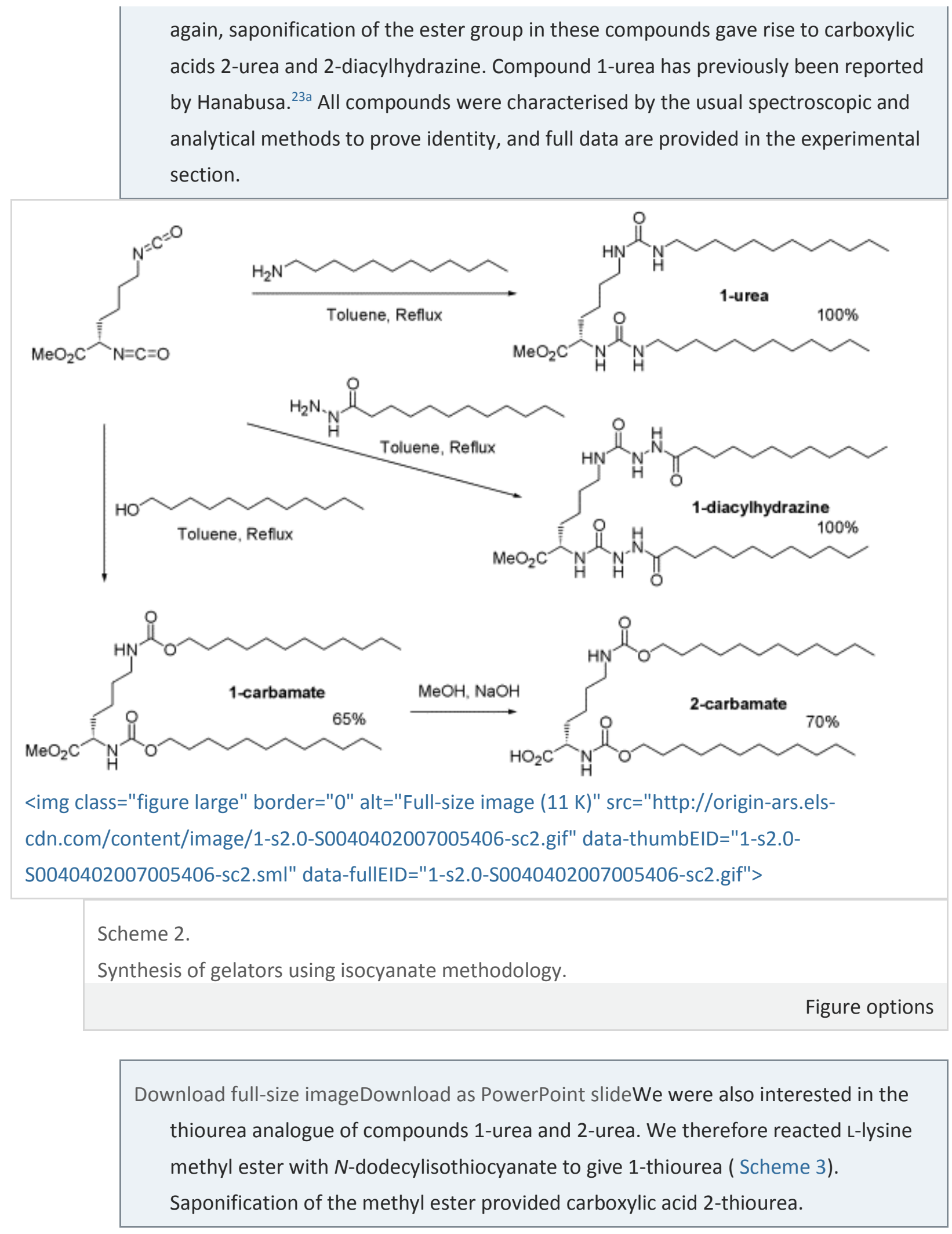




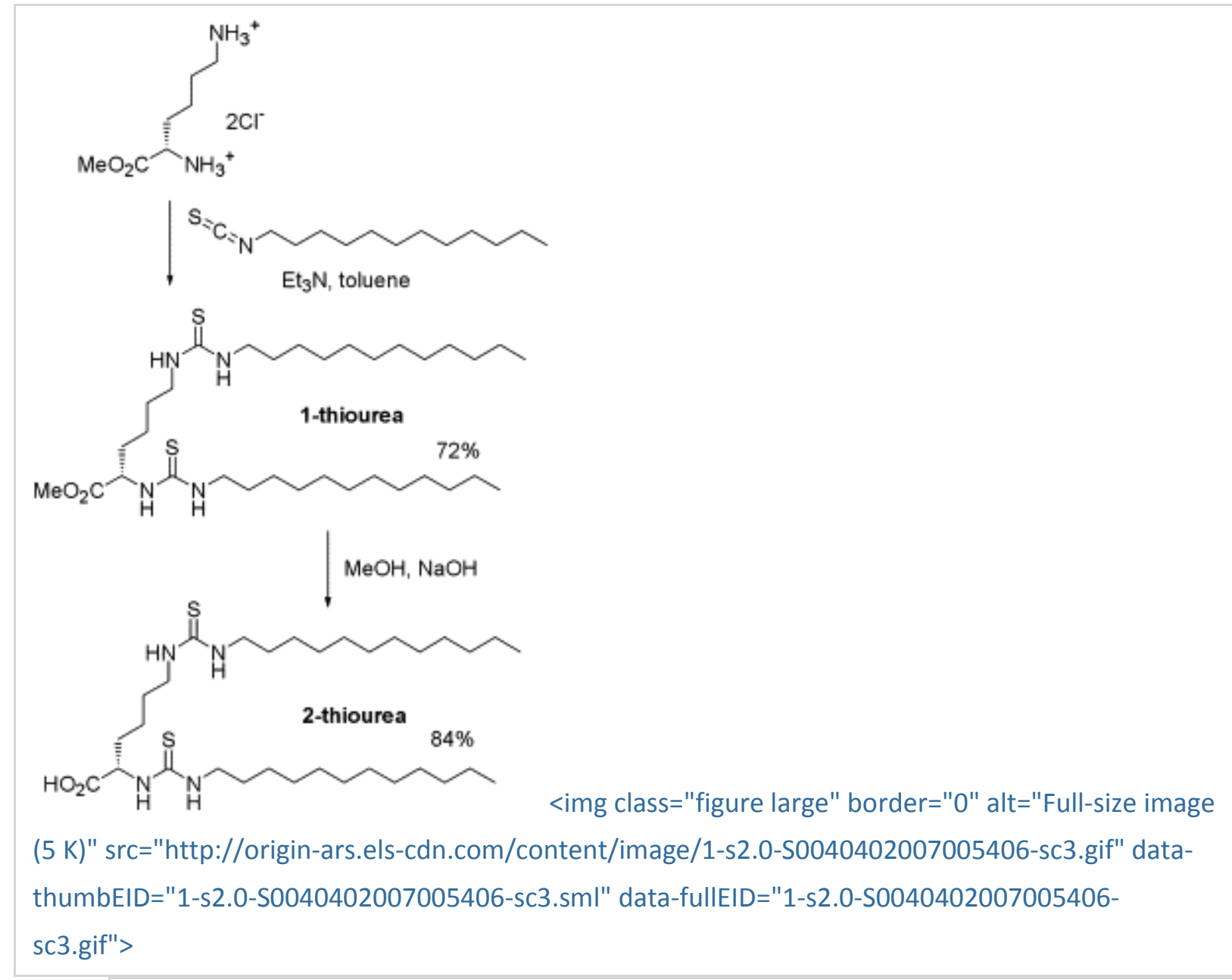

Scheme 3.

Synthesis of compounds 1-thiourea and 2-thiourea.

Figure options

Download full-size imageDownload as PowerPoint slideThe compounds were subsequently investigated by a range of different methods in order to ascertain their ability to self-assemble into nanoscale structures, leading to macroscopic solvent gelation.

\subsection{Thermal stabilities and IR studies}

Initially, we studied the ability of these compounds to gelate toluene across a range of concentrations (Table 1 gives a summary). Typically, samples were prepared by adding compound to the solvent $(1 \mathrm{~mL})$, followed by sonication for $30 \mathrm{~min}$ at ambient temperature. The mixture was heated to $20^{\circ} \mathrm{C}$ below the boiling point of the solvent, allowed to cool to room temperature at a rate of $0.5{ }^{\circ} \mathrm{C}$ per minute and finally left to stand overnight. The gels were investigated after a period of $24 \mathrm{~h}$. This type of process is frequently required for the formation of gels as it provides the molecular building blocks 
with sufficient energy to overcome the kinetic barrier to self-assembly. ${ }^{24}$ Controlled curing of the gel during cooling ensures the formation of soft materials with reproducible properties.

Table 1.

Summary of the gelation ability of compounds investigated in this paper

\section{Compound Appearance in toluene at concentrations of $40 \mathrm{mM}$}

1-Carbamate Solution

1-Amide Viscous solution

1-Urea Gel

1-Diacylhydrazine Gel

1-Thiourea Solution

2-Carbamate Solution

2-Amide Gel

2-Urea Precipitate

2-Diacylhydrazine Precipitate

2-Thiourea Precipitate

All data are provided using toluene as solvent.

Table options

View in workspaceDownload as CSVCompound 1-amide did not lead to a fully formed self-supporting gel, however, some viscosification of the solvent was visually observed. Compound 1-carbamate, however, only formed an isotropic solution, with no increase in viscosity. Comparison of IR spectra of 1-carbamate and 1-amide in cyclohexane, another organic solvent, which can support gelation, clearly demonstrated the differences in the self-assembly of these molecules (Fig. 1). Compound 1-carbamate has its major $\mathrm{N}-\mathrm{H}$ stretch at ca. $3435 \mathrm{~cm}^{-1}$. There is also a broad absorption band at ca. $3365 \mathrm{~cm}^{-1}$. The peak at $3435 \mathrm{~cm}^{-1}$ corresponds to $\mathrm{N}-\mathrm{H}$ groups, which are not involved in hydrogen bond formation, whilst that at $3365 \mathrm{~cm}^{-1}$ corresponds to hydrogen-bonded $\mathrm{N}-\mathrm{H}$ groups. ${ }^{25}$ The presence of a significant IR band for the non-hydrogen-bonded $\mathrm{N}-\mathrm{H}$ groups in 1-carbamate is in agreement with the observation that this compound does not appear to assemble into a structured material. Compound 1-amide, on the other hand, does not have any peaks $>3400 \mathrm{~cm}^{-1}$, and only exhibits peaks at ca. 3345 and $3305 \mathrm{~cm}^{-1}$ indicating the $\mathrm{N}-\mathrm{H}$ groups are probably fully involved in the formation of hydrogen bond interactionsconsistent with the ability of this compound to viscosify toluene. 


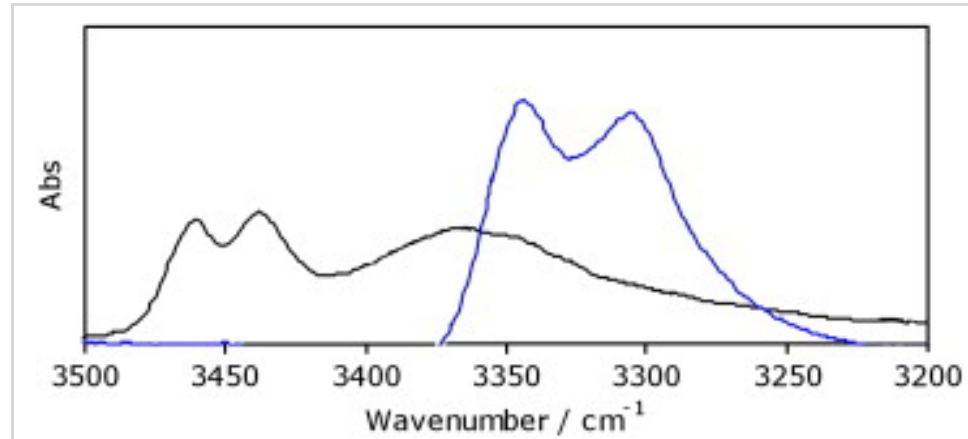

Figure 1.

$\mathrm{N}-\mathrm{H}$ stretching region of the IR spectra of 1-carbamate (black) and 1-amide (blue) measured in cyclohexane at a concentration of $30 \mathrm{mM}$.

Figure options

Download full-size imageDownload as PowerPoint slideThe difference between 1-amide and 1-carbamate can be rationalised in terms of the inherent hydrogen bonding potential of the different linkages. Carbamate groups are less effective hydrogen bond donors than amide groups as a consequence of the $+\mathrm{M}$ mesomeric effect of the adjacent oxygen atom. ${ }^{15 \mathrm{c}}$ The lower strength of the intermolecular hydrogen bond interaction in 1-carbamate should lead to supramolecular oligomers of shorter lengths, which are not able to give rise to macroscopically structured soft materials.

Compound 1-urea had previously been reported to gelate benzene, ${ }^{23 a}$ and therefore we were not surprised that it was an effective gelator of toluene-with a $T_{\text {gel }}$ value of $64{ }^{\circ} \mathrm{C}$ in the concentration independent ('plateau') region ( Fig. 2). Interestingly, compound 1-diacylhydrazine had very similar thermal behaviour to 1-urea with a $T_{\text {gel }}$ value of $62{ }^{\circ} \mathrm{C}$ in the 'plateau' region. Both of these gelators formed gels above a concentration of ca. $20 \mathrm{mM}$ (ca. 1.3\% w/v).

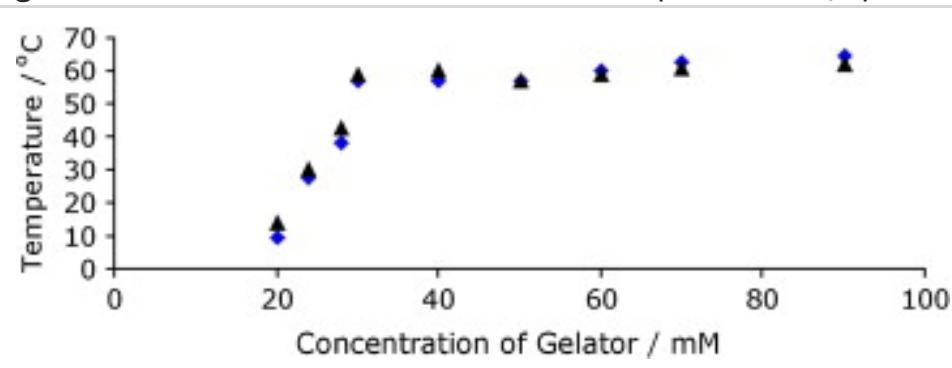

Figure 2.

$T_{\text {gel }}$ values for 1-urea (blue diamonds) and 1-diacylhydrazine (black triangles) in toluene.

Figure options

Download full-size imageDownload as PowerPoint slideThe IR spectra of these compounds in cyclohexane (not shown) indicated no peaks $>3400 \mathrm{~cm}^{-1}$; both compounds had $\mathrm{N}-\mathrm{H}$ stretches between 3300 and $3400 \mathrm{~cm}^{-1}$, consistent with the 
involvement of the $\mathrm{N}-\mathrm{H}$ protons in the formation of hydrogen bond networks. For 1diacylhydrazine, there was also a major peak at ca. $3210 \mathrm{~cm}^{-1}$ consistent with strong, perhaps intramolecular, hydrogen bond interactions. The NMR spectrum of 1diacylhydrazine was also consistent with the presence of intramolecular hydrogen bonds, with some of the $\mathrm{NH}$ resonances occurring significantly downfield (ca. $9 \mathrm{ppm})$. It is also worth noting that 1-diacylhydrazine and 2-diacylhydrazine have anomalously high $\alpha_{D}$ values when compared with the other compound in the series. This effect may be consistent with a folded conformation associated with intramolecular hydrogen bonding in the diacylhydrazine system.

It may have been expected that diacylhydrazine derivatives would form more effective hydrogen bond networks than ureas, due to the presence of extra $\mathrm{N}-\mathrm{H}$ and $\mathrm{C}<\mathrm{img}$ border="0" alt="double bond; length as m-dash" src="http://cdn.els-cdn.com/sd/entities/dbnd" class="glyphlmg">0 groups, but using the data above, we propose that some of these additional hydrogen bonding groups form intramolecular hydrogen bond interactions (evidence above), and are hence unable to contribute fully to the formation of the extended nanoscale intermolecular network.

Compound 1-thiourea was unable to form gels, and instead, an isotropic, optically transparent solution was observed. This was initially surprising, because thioureas are known to be excellent hydrogen bond donors-better than ureas. ${ }^{26}$ However, in this case, the hydrogen bond acceptor would have to be, predominantly, C<img border="0" alt="double bond; length as m-dash" src="http://cdn.els-cdn.com/sd/entities/dbnd" class="glyphlmg">S. Sulfur is a poor hydrogen bond acceptor, and we therefore propose that compound 1-thiourea is unable to establish an effective sample-spanning hydrogen-bonded network due to these ineffective hydrogen-bond acceptor groups.

Overall, these observations indicate that the molecular recognition pathways, which underpin the gelation of these molecules intimately involve the hydrogen bonding groups. Compounds with insufficient hydrogen-bond potential are simply soluble in organic solvents, whilst greater hydrogen bonding potential leads to more effective gels. For example, ureas and diacylhydrazines are more effective hydrogen bond donors than amides or carbamates as a consequence of their ability to form multiple hydrogen bond interactions. These hydrogen bond rich linkages are thus able to underpin gels with significantly higher thermal stabilities.

\subsection{Field emission gun scanning electron microscopy (FEG-SEM)}

Field emission gun scanning electron microscopy (FEG-SEM) has been widely used as a comparative technique for investigating dried gel-phase materials, and can provide a unique visual insight into the nanoscopic structures, which underpin gelation. Samples of 1-carbamate, 1-amide, 1-urea and 1diacylhydrazine in toluene were allowed to dry, and the morphologies illustrated in Figure 3 were 
observed. As expected for a system, which did not exhibit any structuring of the solvent, 1-carbamate did not yield ordered assemblies (Fig. 3A). Compound 1-amide gave rise to ribbon-like objects with a superhelical twist and diameters of ca. $100 \mathrm{~nm}$ (Fig. 3B). All of these fibres appeared to have right handed helicity, clearly demonstrating the transcription of molecular scale chirality into the nanoscale chiral organisation. These superhelical ribbons were loosely crosslinked, consistent with the fact that 1-amide only caused solvent viscosification and did not lead to a fully formed gel. On the other hand, 1-urea (Fig. 3C) and 1-diacylhydrazine (Fig. 3D) formed nanoscale morphologies, which consisted of multiple interacting narrow fibrils, clearly aggregated into a network-consistent with the observation of effective macroscopic gelation.
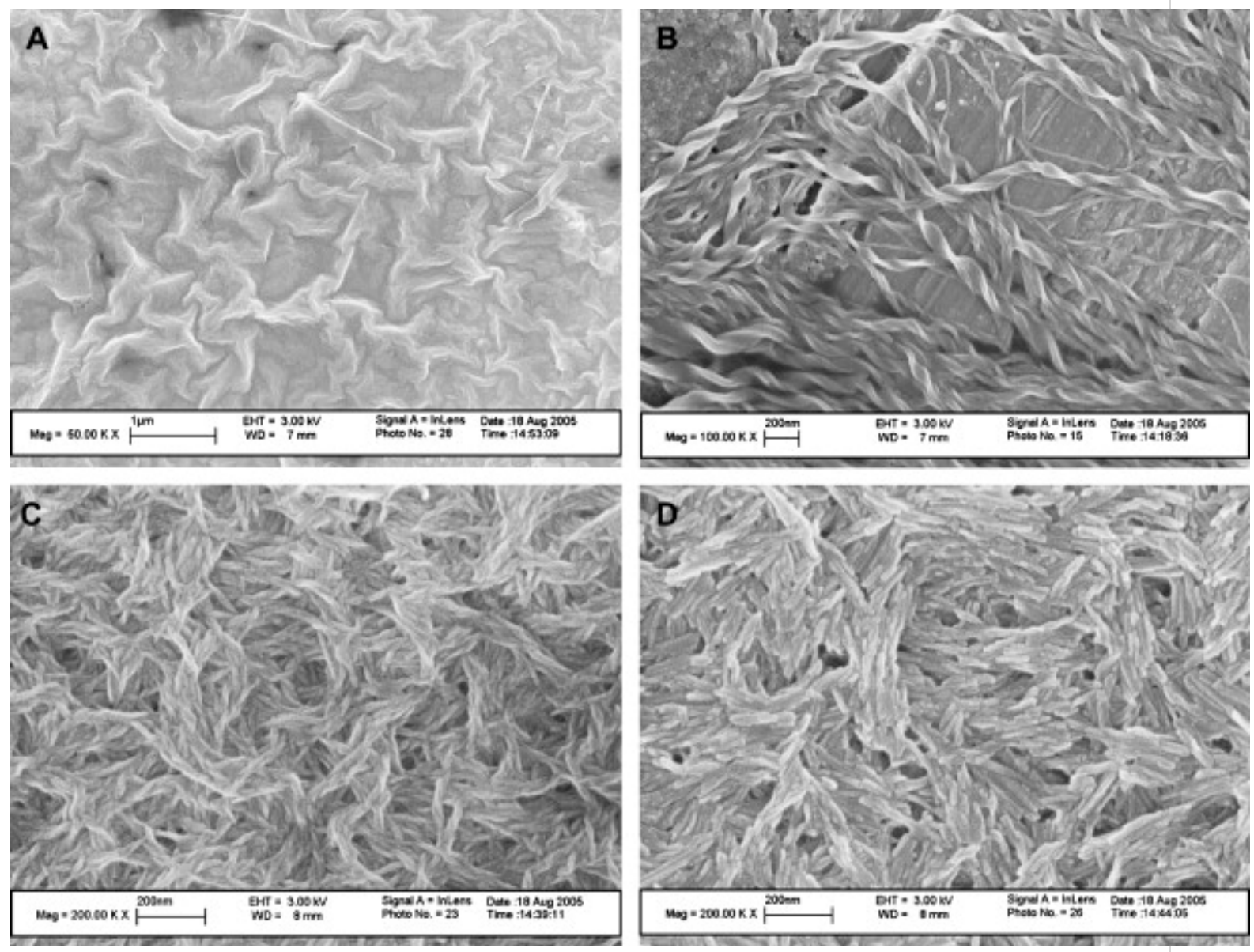

Figure 3.

SEM images of samples dried from toluene: (A) 1-carbamate, (B) 1-amide, (C) 1-urea and (D) 1-diacylhydrazine (all $3 \mathrm{mM}$ ). 
Download full-size imageDownload as PowerPoint slide2.4. Circular dichroism (CD) spectroscopy

In order to gain greater information about the nanoscale self-assembly process responsible for gelation, we performed CD spectroscopic studies. CD spectroscopy ${ }^{27}$ is widely used to determine the secondary structure of proteins (e.g., $\alpha$-helix), ${ }^{28}$ and is an ideal method for probing the organisation of gelator building blocks within a chiral nanostructured environment. We have previously made use of $C D$ methods to demonstrate the organisation of gelators within a chiral environment as mediated by exciton coupling between the adjacent amide groups. These amide groups absorb at ca. $220 \mathrm{~nm}$, and consequently, we must employ a solvent, which supports gelation, but is UV-silent in this spectral region. On this occasion, the solvent of choice for our studies was methylcyclohexane as it was the best general solvent for these gelators. However, this still prevented the comparative study of 1-amide due to its lack of solubility.

Compound 1-carbamate gave a CD signal with an ellipticity of 30 mdeg at a concentration of $3 \mathrm{mM}$. However, the intensity was directly proportional to gelator concentration, and we could therefore assign this to the inherent $C D$ signal of the non-aggregated molecule. We have previously observed that many gelators have a small inherent CD signal, but that if they self-assemble, the assemblies exhibit a much larger signal, which is dependent on temperature, and also dependent on concentration in a non-linear manner.

Compounds 1-urea and 1-diacylhydrazine both exhibited CD bands (Fig. 4), which could be assigned to the assembly of the molecular building blocks into a chiral nanostructure. Gelator 1-urea gave a band with an ellipticity of $+55 \mathrm{mdeg}$ at ca. $210 \mathrm{~nm}$ (Fig. 4A). Gelator 1-diacylhydrazine, on the other hand, gave a Cotton effect band, centred at $230 \mathrm{~nm}$, with ellipticities of +110 mdeg at $220 \mathrm{~nm}$ and $-110 \mathrm{~nm}$ at $240 \mathrm{~nm}$ (Fig. 4B). This clearly indicates that the CONH chromophores within these two gelators respond to their organisation within a chiral nanoscale environment in different waysindicating that even though these gels have similar thermal stabilities and SEM morphologies, there are subtle differences in their chiral assembly processes.

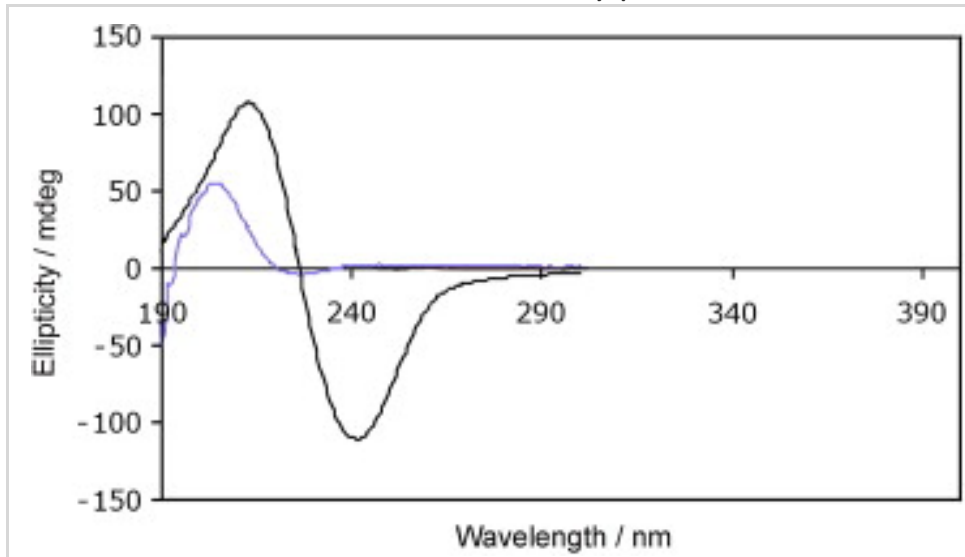

Figure 4. 
CD spectra of compounds 1-urea (blue) and 1-diacylhydrazine (black)-measured in methylcyclohexane with a gelator concentration of $3 \mathrm{mM}$.

Figure options

Download full-size imageDownload as PowerPoint slideThere have been extensive developments of $\mathrm{CD}$ spectroscopic fitting to understand the conformational preferences of proteins and polymers. ${ }^{28}$ However, the translation of these theories to provide a full understanding of the self-assembly of non-covalent assemblies based on peptide-like molecules (in which the chromophoric groups are not all amides, having instead subtle variations in hydrogen bonding units) is not a straightforward task and will not be attempted here. Nonetheless, these results agree with the thermal studies and support the theory that 1-urea and 1-hydrazine both form effective hydrogen-bonded chiral nanostructures capable of supporting gel-phase materials.

\subsection{Studies of acid-functionalised gelators}

Given the inability of 1-amide and 1-carbamate to form sample-spanning gels, we then investigated the effect of removing the methyl ester from the focal point to unmask a carboxylic acid. The resultant compounds, 2-amide and 2-carbamate, were investigated for their ability to form gels. The simple change of ester to acid enabled 2-amide to form gels in toluene with low thermal stabilities-the $T_{\text {gel }}$ value in the plateau region was only ca. $20^{\circ} \mathrm{C}$ ( Fig. 5, blue). Compound 2-carbamate, however, still gave rise to an isotropic solution. Once again, these results can be rationalised in terms of the inherent hydrogen bonding potential, with carbamates being less able to support the formation of an intermolecular hydrogen-bonded network.

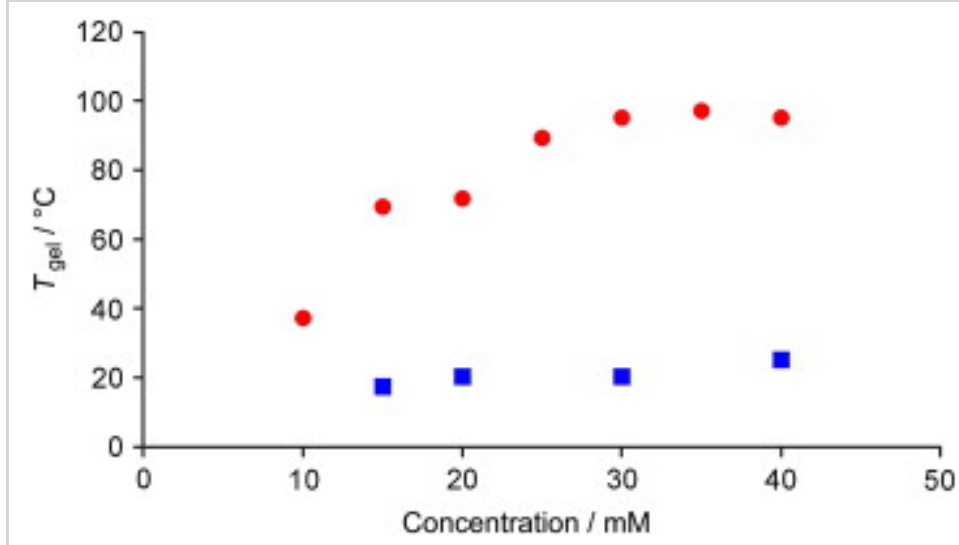

Figure 5.

$T_{\text {gel }}$ values for 2-amide in toluene in the absence (blue squares) and presence (red circles) of diaminododecane (0.5 equiv). 
Download full-size imageDownload as PowerPoint slideln contrast to 2-amide and 2carbamate, compounds 2-urea, 2-diacylhydrazine and 2-thiourea failed to dissolve in the organic solvents investigated in this study, and were therefore unable to gelate or viscosify these solvents. We propose that the high polarity of these compounds, which have high numbers of hydrogen bond donors/acceptors, prevents their solubility and hence stops them from establishing a fibrillar nanostructured gel.

These results indicate that compounds with insufficient hydrogen-bond potential are simply soluble in organic solvents, while those with too much hydrogen bond potential appear to remain as insoluble precipitates. It is only those compounds with the correct balance of hydrogen bonding functionality and solubilising organic segments (e.g., alkyl chains) that are able to establish sample-spanning, gelphase networks.

We then investigated the addition of a long chain aliphatic diamine to gelators 2-amide and 2carbamate, to determine whether the formation of a two-component system would enhance the selfassembly into a gel-phase material (Fig. 6). Such two-component systems have been of intense recent literature interest. ${ }^{29}$ Combining 2-amide with diaminododecane enhanced the $T_{\text {gel }}$ value of the resultant gels to a value of $95^{\circ} \mathrm{C}$, much higher than the $T_{\text {gel }}$ value of 2-amide in the absence of the diamine ( Fig. 5). Furthermore, room temperature gels were formed at concentrations as low as $10 \mathrm{mM}$. We therefore propose that the two-component complex is more effectively pre-organised to form a fibrillar nanoscale self-assembled network. Compound 2-carbamate was unable to form gels in the presence of diaminododecane, however, the mixture did lead to solvent viscosification-again indicating a greater preference for self-assembly for the two-component complex.

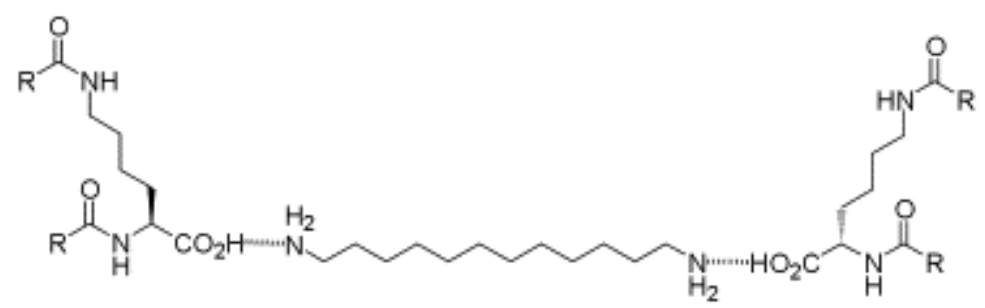

Figure 6.

Two-component complex formed as a consequence of acid-base interactions.

Figure options

Download full-size imageDownload as PowerPoint slideCompound 2-amide gave an SEM image, which consisted of a very loosely crosslinked network of rigid tapes ca. 1$3 \mu \mathrm{m}$ in width (Fig. 7A). It is clear that this morphology, which has considerable crystallinity and exists on the microscale, rather than the nanoscale, would not be expected to support such an effective gel-consistent with the observation that this compound only forms gels with low thermal stability. However, it should be noted 
that the morphology may be driven into this crystalline form during the drying process (although this would also imply a nanoscale gel morphology, which lacks stability). In contrast, on the addition of diaminododecane to 2 -amide, a nanoscale network typical of an effective gel-phase assembly was obtained. This consisted of interpenetrating fibres with diameters ca. 100-200 nm (Fig. 7B). This is consistent with the dramatic increase in thermal stability observed on the addition of the second component to 2-amide.
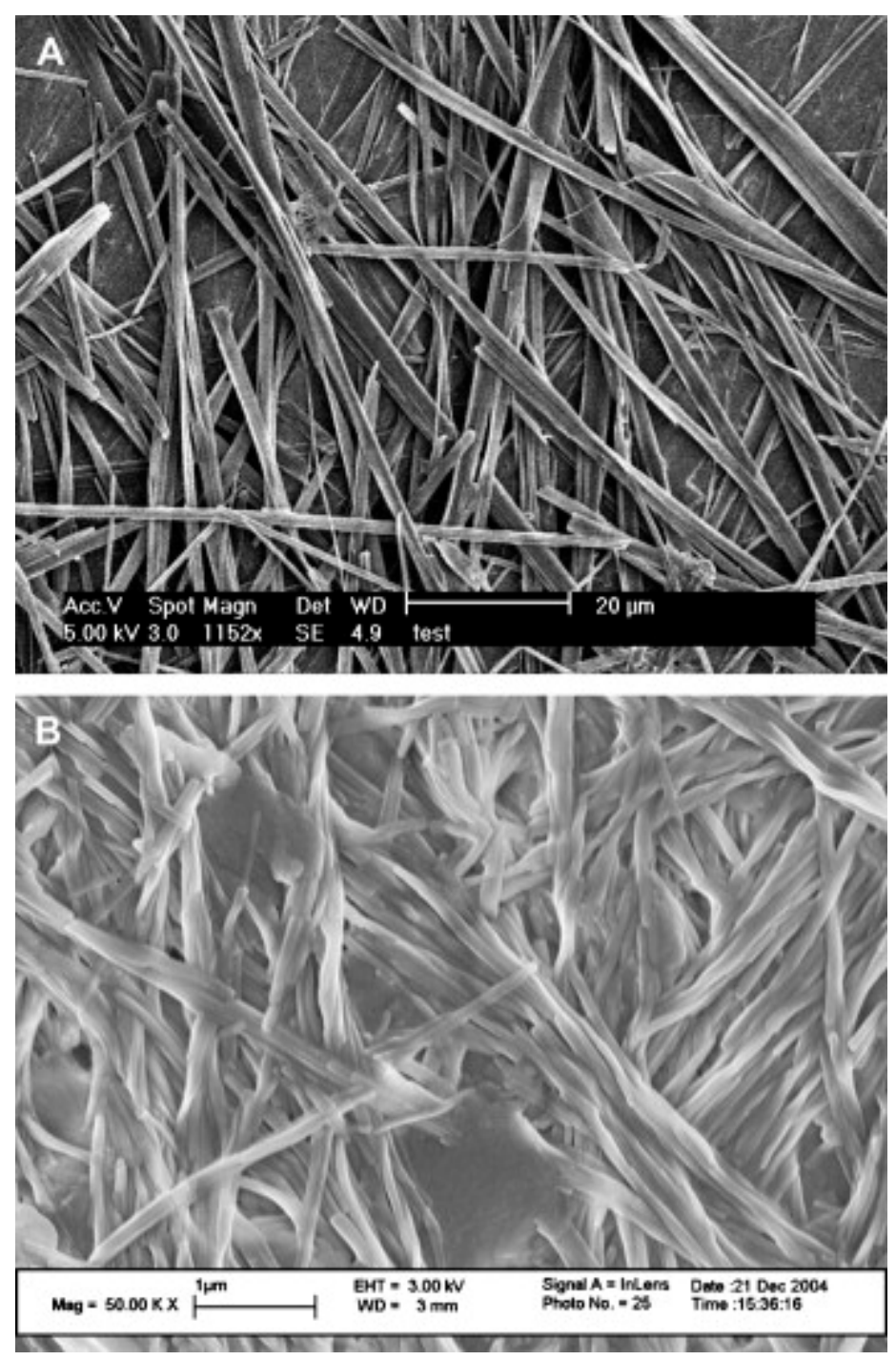

Figure 7.

SEM images of samples dried from toluene of: (A) gelator 2-amide (3 $\mathrm{mM})($ scale bar=20 $\mu \mathrm{m})$ and (B) gelator 2-amide (3 mM)+diaminododecane (1.5 mM) (scale bar=1 $\mu \mathrm{m})$.

Figure options

Download full-size imageDownload as PowerPoint slide2.6. Gelation of industrially relevant solvents 
Although toluene, cyclohexane and methylcyclohexane are ideal solvents for investigating gelator molecules in the laboratory, we decided it would also be interesting to investigate the potential of these systems to rigidify solvents with applications in modern technology. We therefore chose to investigate a range of different solvents. We investigated organic solvent media obtained from fossil fuels (fuel oils), from renewable plant resources (i.e., plant oils) and solvents widely used in pharmaceutical formulation (e.g., long chain fatty acid esters). ${ }^{30}$ Similar solvents have been previously gelated by other researchers active in the area of low molecular weight gels. ${ }^{20 m}$

Compound 2-amide, when combined with diaminododecane, was able to form two-component gels in a wide range of solvents. Figure 8 illustrates the thermal behaviour in terms of the $T_{\text {gel }}$ values obtained using 2-amide $(20 \mathrm{mM})$ and diaminododecane $(10 \mathrm{mM})$ - a total loading of ca. $1.2 \% \mathrm{wt} / \mathrm{vol})$. We have therefore demonstrated that this gelator, containing a simple combination of biocompatible fatty acids and amino acids is able to immobilise a wide range of industrially valuable organic media.

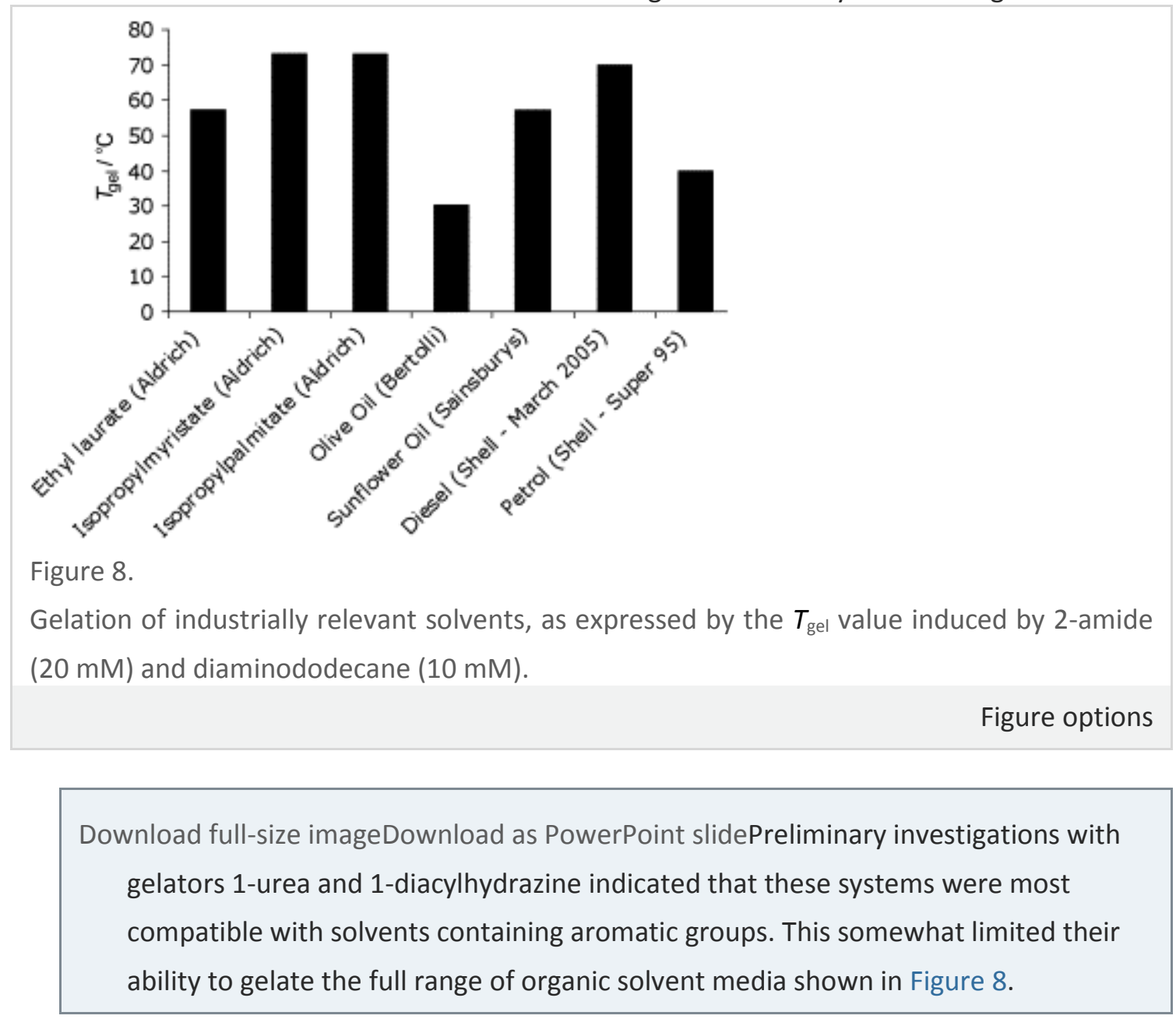

\section{Conclusions}

The results in this paper report the systematic modification of the hydrogen bonding linkage between alkyl chains and an amino acid building block to construct a small library of gelators. The ability of these compounds to gelate organic solvents, and generate nanoscale hydrogen bonding networks, 
can be directly related to the ability of the linking group to form intermolecular hydrogen bonds. In general terms, the ability to structure solvents can be considered as: thiourea<carbamate<amide<urea diacylhydrazine.

We have demonstrated that the less effective amide and carbamate gelators can generally be enhanced by converting the ester group to a carboxylic acid, and subsequently mixing the acid with a second component (diaminododecane). This changes the molecular structure of the building block responsible for gelation and directly enhances the ability to form nanoscale networks. The resultant two-component gel is capable of immobilising a wide range of solvents of industrial interest including petrol and diesel (fuel oils), olive oil and sunflower oil (food/fuel oils from renewable resources) and ethyl laurate, isopropyl myristate and ispropyl palmitate (oils used widely in pharmaceutical formulation).

\section{Experimental}

\subsection{Materials and methods}

Reagents and solvents were commercially available and used as supplied without further purification unless otherwise stated. L-Lysine methyl ester was synthesised using literature methodology. ${ }^{31}$ Compound 1-urea had previously been reported by Hanabusa and co-workers and data are therefore not provided here. ${ }^{23 a}$ All solutions of $\mathrm{NaHCO}_{3}$ are saturated aqueous solutions. All solutions of $\mathrm{NaHSO}_{4}$ are aqueous solutions ( $160 \mathrm{~g} \mathrm{dm}^{-3}$ ). Column chromatography was performed on silica using silica gel provided by Fluka Ltd. (35-70 $\mu \mathrm{m})$, while TLC was performed on aluminium-backed plates coated with $0.25 \mathrm{~mm}$ silica gel 60 (Merck). Spots were visualised by use of an appropriate stain (ninhydrin solution $0.2 \%$ (by mass) in ethanol or cerium molybdate stain: water $(180 \mathrm{~mL})$, concd $\mathrm{H}_{2} \mathrm{SO}_{4}(20 \mathrm{~mL})$, ammonium dimolybdate $5 \mathrm{~g}$, cerium sulfate $2 \mathrm{~g}$ ). NMR chemical shifts $(\delta)$ are reported in parts per million downfield of tetramethylsilane using residual solvent as internal reference. All spectra were recorded on a JEOL ECX400 $\left({ }^{1} \mathrm{H} 400 \mathrm{MHz},{ }^{13} \mathrm{C} 100 \mathrm{MHz}\right)$ spectrometer. Electrospray and high-resolution FAB were recorded on a Thermo-Finnigan LCQ mass spectrometer and Micromass Autospec, respectively. Infrared spectra were recorded using a Nicolet Avatar 360 FTIR spectrometer.

\subsection{Synthesis and characterisation}

\subsubsection{Compound 1-amide}

L-Lysine methyl ester dihydrochloride ( $1.50 \mathrm{~g}, 6.4 \mathrm{mmol}$, 1 equiv) was suspended in $\mathrm{DCM}(50 \mathrm{~mL})$. Et ${ }_{3} \mathrm{~N}$ ( $4.50 \mathrm{~mL}, 32 \mathrm{mmol}, 5$ equiv) and dodecanoic acid chloride $(3.00 \mathrm{~mL}, 12.8 \mathrm{mmol}, 2$ equiv) were added to this suspension and stirred for $24 \mathrm{~h}$ under nitrogen. The precipitate was removed by filtration, washed with DCM and discarded. The filtrate was washed with $\mathrm{NaHCO}_{3}, \mathrm{NaHSO}_{4}, \mathrm{NaHCO}_{3}$, water and finally brine; then dried over $\mathrm{MgSO}_{4}$. The volatiles were removed by rotary evaporation, and the 
resulting solid was purified by silica column chromatography (DCM-MeOH, 98:2). After rotary evaporation, 1-amide was obtained as a white solid, which was dried under high vacuum for $24 \mathrm{~h}$, yielding $2.50 \mathrm{~g}(4.8 \mathrm{mmol}, 75 \%) .{ }^{1} \mathrm{H} \mathrm{NMR}\left(400 \mathrm{MHz}, \mathrm{CD}_{3} \mathrm{OD}\right) \delta_{\mathrm{H}} 6.38-6.36(1 \mathrm{H}, \mathrm{d}, \mathrm{J}=7.8 \mathrm{~Hz}, \mathrm{NH}), 6.00-$ $5.90(1 \mathrm{H}, \mathrm{t}, \mathrm{J}=5.3 \mathrm{~Hz}, \mathrm{NH}), 4.51(1 \mathrm{H}, \mathrm{dd}, \mathrm{J}=8.5,4.7 \mathrm{~Hz}, \mathrm{COCH}(\mathrm{R}) \mathrm{NH}), 3.69\left(3 \mathrm{H}, \mathrm{s}, \mathrm{CO}_{2} \mathrm{CH}_{3}\right), 3.18-3.15(2 \mathrm{H}$, m, $\left.\mathrm{CH}_{2} \mathrm{NH}\right), 2.19\left(2 \mathrm{H}, \mathrm{t}, \mathrm{J}=7.0 \mathrm{~Hz}, \mathrm{NHCOCH}_{2}\right), 2.16\left(2 \mathrm{H}, \mathrm{t}, \mathrm{J}=7.3 \mathrm{~Hz}, \mathrm{NHCOCH}_{2}\right), 1.87-1.20\left(42 \mathrm{H}, \mathrm{m}, \mathrm{CH}_{2}\right)$, $0.90\left(6 \mathrm{H}, \mathrm{t}, J=6.6 \mathrm{~Hz}, \mathrm{CH}_{3}\right) .{ }^{13} \mathrm{C} \mathrm{NMR}\left(100 \mathrm{MHz}, \mathrm{CD}_{3} \mathrm{OD}\right) \delta_{\mathrm{C}} 176.30(\mathrm{CONH} \times 2), 174.26\left(\mathrm{CO}_{2} \mathrm{Me}\right), 52.36$ $(\mathrm{COCH}(\mathrm{R}) \mathrm{NH}), 51.76\left(\mathrm{COOCH}_{3}\right), 40.10,37.18,36.83,33.09,30.77,30.68,30.65,30.49,30.45,30.31$, 29.96, 27.11, 27.00, 24.30, 23.75 (all $\mathrm{CH}_{2}$ ), $14.45\left(\mathrm{CH}_{3} \times 2\right)$. IR ( $\mathrm{KBr}$ disc) $v_{\max } \mathrm{cm}^{-1} 3323(\mathrm{NH}), 1744$ (C <img border="0" alt="double bond; length as m-dash" src="http://cdn.els-cdn.com/sd/entities/dbnd" class="glyphlmg">0, ester), 1640 ( $C<$ img border="0" alt="double bond; length as m-dash" src="http://cdn.els-cdn.com/sd/entities/dbnd" class="glyphlmg">0, amide), 1544 (CONH). ESI-MS $(\mathrm{m} / \mathrm{z})$ calculated value for $\mathrm{C}_{31} \mathrm{H}_{60} \mathrm{~N}_{2} \mathrm{O}_{4}[\mathrm{M}]$ requires: 524; $\left(\mathrm{ES}^{+}\right)$found: $547\left(100 \%\right.$, $\left.[\mathrm{M}+\mathrm{Na}]^{+}\right)$. HR-FAB $(\mathrm{m} / \mathrm{z}) \mathrm{C}_{31} \mathrm{H}_{60} \mathrm{~N}_{2} \mathrm{O}_{4} \mathrm{Na}[\mathrm{M}+\mathrm{Na}]^{+}$calculated: 547.4451; found: 547.4443. $R_{f} 0.23$ (DCM-MeOH 90:10, CeMo stain). $\mathrm{Mp} 82-84^{\circ} \mathrm{C} ;[\alpha]_{\mathrm{D}}{ }^{293}+4.3\left(\right.$ ( $\left.1.0, \mathrm{CHCl}_{3}\right)$.

\subsubsection{Compound 2-amide}

Compound 1-amide (1.36 g, $2.6 \mathrm{mmol}, 1$ equiv) was dispersed in $\mathrm{MeOH}$ (30 mL), aqueous $\mathrm{NaOH}$ (7.8 mL, 1M, $7.8 \mathrm{mmol}, 3$ equiv) was added and the mixture stirred for $3 \mathrm{~d}$. The volatiles were removed by rotary evaporation, and water $(100 \mathrm{~mL})$ was added and then acidified to $\mathrm{pH} 3$ with $\mathrm{NaHSO}_{4}$. The solid was collected by filtration, washed with water and finally dried under high vacuum for $48 \mathrm{~h}$, yielding $1.22 \mathrm{~g}$ of 2 -amide $(2.4 \mathrm{mmol}, 92 \%)$ as a white solid. ${ }^{1} \mathrm{H} N M R\left(400 \mathrm{MHz}, \mathrm{CD}_{3} \mathrm{OD}\right) \delta_{\mathrm{H}} 6.37(1 \mathrm{H}, \mathrm{d}$, $J=7.8 \mathrm{~Hz}, \mathrm{NH}), 5.95(1 \mathrm{H}, \mathrm{t}, \mathrm{J}=5.3 \mathrm{~Hz}, \mathrm{NH}), 4.35(1 \mathrm{H}, \mathrm{dd}, \mathrm{J}=9.1,4.7 \mathrm{~Hz}, \mathrm{COCH}(\mathrm{R}) \mathrm{NH}), 3.17(2 \mathrm{H}, \mathrm{t}, \mathrm{J}=7 \mathrm{~Hz}$, $\left.\mathrm{CH}_{2} \mathrm{NH}\right), 2.24\left(2 \mathrm{H}, \mathrm{t}, \mathrm{J}=7.0 \mathrm{~Hz}, \mathrm{NHCOCH}_{2}\right), 2.16\left(2 \mathrm{H}, \mathrm{t}, \mathrm{J}=7.3 \mathrm{~Hz}, \mathrm{NHCOCH}_{2}\right), 1.87-1.20\left(42 \mathrm{H}, \mathrm{m}, \mathrm{CH}_{2}\right)$, $0.90\left(6 \mathrm{H}, \mathrm{t}, \mathrm{J}=6.6 \mathrm{~Hz}, \mathrm{CH}_{3}\right) .{ }^{13} \mathrm{C} \mathrm{NMR}\left(100 \mathrm{MHz}, \mathrm{CD}_{3} \mathrm{OD}\right) \delta_{\mathrm{C}} 176.30(\mathrm{CONH} \times 2), 173.82\left(\mathrm{CO}_{2} \mathrm{H}\right), 52.36$ (COCH(R)NH), 40.00, 37.18, 36.83, 33.09, 30.76, 30.68, 30.65, 30.49, 30.45, 30.34, 29.96, 27.11, 27.00, 24.30, 23.75 (all $\mathrm{CH}_{2}$ ), $14.45\left(\mathrm{CH}_{3} \times 2\right)$. IR ( $\mathrm{KBr}$ disc) $v_{\max } \mathrm{cm}^{-1} 3323(\mathrm{NH}), 1713$ (C<img border="0"

alt="double bond; length as m-dash" src="http://cdn.els-cdn.com/sd/entities/dbnd" class="glyphlmg">0, carboxylic acid), 1646 (C<img border="0" alt="double bond; length as $\mathrm{m}$-dash" src="http://cdn.els-cdn.com/sd/entities/dbnd" class="glyphlmg">0, amide), 1557 (CONH). ESI-MS $(\mathrm{m} / \mathrm{z})$ calculated value for $\mathrm{C}_{30} \mathrm{H}_{58} \mathrm{~N}_{2} \mathrm{O}_{4}[\mathrm{M}]$ requires: 510; $\left(\mathrm{ES}^{+}\right)$found: $533.4\left(100 \%,[\mathrm{M}+\mathrm{Na}]^{+}\right) ;\left(\mathrm{ES}^{-}\right)$ found: $509\left(100 \%,[M-H]^{-}\right)$. HR-FAB $(m / z) \mathrm{C}_{30} \mathrm{H}_{57} \mathrm{~N}_{2} \mathrm{O}_{4} \mathrm{Na}_{2}[\mathrm{M}+2 \mathrm{Na}-\mathrm{H}]^{+}$calculated 555.4114; found: 555.4122. $R_{f} 0.10$ (DCM-MeOH 90:10, CeMo stain). Mp 105-107 ${ }^{\circ} \mathrm{C} ;[\alpha]_{\mathrm{D}}^{293}+2.2$ (c 1.0, $\mathrm{CHCl}_{3}$ ).

\subsubsection{Compound 1-carbamate}

Dodecanol (7.63 g, $41 \mathrm{mmol}, 2.05$ equiv) was added to a solution of methyl 2,6-diisocyanatohexanoate (lysine diisocyanate, LDI) $(4.24 \mathrm{~g}, 3.66 \mathrm{~mL}, 20 \mathrm{mmol}, 1$ equiv) in toluene (100 mL). The solution was stirred for $16 \mathrm{~h}$ at $100{ }^{\circ} \mathrm{C}$, after which time the volatiles were removed by rotary evaporation. Two 
recrystallisations from methanol-diethyl ether (100 mL, 1:1) and subsequent filtration, followed by $24 \mathrm{~h}$ under high vacuum resulted in 1-carbamate as a white solid in $65 \%$ yield $(7.60 \mathrm{~g}, 13 \mathrm{mmol}) .{ }^{1} \mathrm{H}$ NMR (400 MHz, DMSO) $\delta_{\mathrm{H}} 5.70(1 \mathrm{H}, \mathrm{br} d, \mathrm{NH}), 5.13(1 \mathrm{H}, \mathrm{br} \mathrm{d}, \mathrm{NH}), 4.28-4.19(1 \mathrm{H}, \mathrm{m}, \mathrm{COCH}(\mathrm{R}) \mathrm{NH})$, 3.99-3.81 (4H, br m, OCH $)$, 3.67 (3H, s, $\left.\mathrm{CO}_{2} \mathrm{CH}_{3}\right), 3.12-2.99\left(2 \mathrm{H}, \mathrm{m}, \mathrm{CH}_{2} \mathrm{NH}\right), 1.87-1.05\left(46 \mathrm{H}, \mathrm{m}, \mathrm{CH}_{2}\right)$, 0.88-0.84 (6H, t, J=6.6 Hz, CH $).{ }^{13} \mathrm{C}$ NMR (100 MHz, DMSO) $\delta_{\mathrm{C}} 173.26\left(\mathrm{CO}_{2} \mathrm{Me}\right), 156.31$ (OCONH×2), 63.84, $63.77\left(\mathrm{CH}_{2} \mathrm{O}\right), 52.37(\mathrm{COCH}(\mathrm{R}) \mathrm{NH}), 51.78\left(\mathrm{COOCH}_{3}\right), 31.14,30.15,30.02,28.87,28.85,28.81$, 28.55, 21.92 (all $\mathrm{CH}_{2}$ ), $13.74\left(\mathrm{CH}_{3} \times 2\right)$, DMSO solvent peak obscures $\mathrm{CH}_{2} \mathrm{NH}$ at ca. $40 \mathrm{ppm}$. IR ( $\mathrm{KBr}$ disc) $v_{\max } \mathrm{cm}^{-1} 3307(\mathrm{NH}), 1741$ (C<img border="0" alt="double bond; length as m-dash" src="http://cdn.els-cdn.com/sd/entities/dbnd" class="glyphlmg">0, ester), 1725 (C<img border="0" alt="double bond; length as m-dash" src="http://cdn.els-cdn.com/sd/entities/dbnd" class="glyphImg">O, carbamate), 1535 (CONH). ESI-MS (m/z) calculated value for $\mathrm{C}_{33} \mathrm{H}_{64} \mathrm{~N}_{2} \mathrm{O}_{6}[\mathrm{M}]$ requires: 584.5; $\left(\mathrm{ES}^{+}\right)$found: $607.5\left(100 \%,[\mathrm{M}+\mathrm{Na}]^{+}\right)$. HR-FAB $(\mathrm{m} / \mathrm{z}) \mathrm{C}_{33} \mathrm{H}_{64} \mathrm{~N}_{2} \mathrm{O}_{6} \mathrm{Na}[\mathrm{M}+\mathrm{Na}]^{+}$requires: 607.4662; found: 607.4661. $[\alpha]_{\mathrm{D}}^{293}+5.9\left(c 1.0, \mathrm{CHCl}_{3}\right)$.

\subsubsection{Compound 2-carbamate}

Compound 1-carbamate ( $2.50 \mathrm{~g}, 4.27 \mathrm{mmol}, 1$ equiv) was suspended in $\mathrm{MeOH}(25 \mathrm{~mL})$ and then aqueous $\mathrm{NaOH}(15 \mathrm{~mL}, 1 \mathrm{M}, 15 \mathrm{mmol}, 3.5$ equiv) was added. The reaction mixture was stirred for $48 \mathrm{~h}$ under nitrogen. The solvent was removed by rotary evaporation, water $(35 \mathrm{~mL})$ added and then the mixture was acidified to $\mathrm{pH} 3$ with $\mathrm{NaHSO}_{4}$. A white solid resulted that was collected by filtration, washed with water and then dried under high vacuum for $48 \mathrm{~h}$, yielding 2-carbamate as a white solid (1.71 g, $3.0 \mathrm{mmol}, 70 \%) .{ }^{1} \mathrm{H}$ NMR $(400 \mathrm{MHz}, \mathrm{DMSO}) \delta_{\mathrm{H}} 7.18(1 \mathrm{H}, \mathrm{br} \mathrm{d}, \mathrm{NH}), 7.01(1 \mathrm{H}, \mathrm{br} \mathrm{d}, \mathrm{NH}), 3.92-$ $3.83\left(4 \mathrm{H}, \mathrm{br} m, \mathrm{OCH}_{2}\right), 3.83-3.71(1 \mathrm{H}, \mathrm{m}, \mathrm{COCH}(\mathrm{R}) \mathrm{NH}), 2.92-2.85\left(2 \mathrm{H}, \mathrm{m}, \mathrm{CH}_{2} \mathrm{NH}\right), 1.67-0.93(46 \mathrm{H}, \mathrm{m}$, $\left.\mathrm{CH}_{2}\right), 0.83-0.76\left(6 \mathrm{H}, \mathrm{t}, \mathrm{J}=6.6 \mathrm{~Hz}, \mathrm{CH}_{3}\right) .{ }^{13} \mathrm{C} \mathrm{NMR}(100 \mathrm{MHz}, \mathrm{DMSO}) \delta_{\mathrm{c}} 173.77\left(\mathrm{CO}_{2} \mathrm{Me}\right), 156.34(\mathrm{CONH} \times 2)$, 63.92, $63.65\left(\mathrm{CH}_{2} \mathrm{O}\right), 53.85(\mathrm{COCH}(\mathrm{R}) \mathrm{NH}), 51.78\left(\mathrm{COCH}_{3}\right), 32.19,30.34,30.01,28.87,28.85,28.81$, 28.55, 22.14, 21.92 (all $\left.\mathrm{CH}_{2}\right), 14.02\left(\mathrm{CH}_{3} \times 2\right)$, DMSO solvent peak obscures $\mathrm{CH}_{2} \mathrm{NH}$ at ca. $40 \mathrm{ppm}$. IR $(\mathrm{KBr}$ disc) $v_{\max } \mathrm{cm}^{-1} 3325(\mathrm{NH}), 1720$ ( $\mathrm{C}<\mathrm{img}$ border="0" alt="double bond; length as m-dash" src="http://cdn.els-cdn.com/sd/entities/dbnd" class="glyphlmg">O, carbamate), 1685 (C<img border="0" alt="double bond; length as m-dash" src="http://cdn.els-cdn.com/sd/entities/dbnd" class="glyphImg">O, carboxylic acid), 1536 (CONH). ESI-MS (m/z) calculated value for $\mathrm{C}_{32} \mathrm{H}_{62} \mathrm{~N}_{2} \mathrm{O}_{6}[\mathrm{M}]$ requires: 570.5; $\left(\mathrm{ES}^{+}\right)$found: $593.5\left(100 \%,[\mathrm{M}+\mathrm{Na}]^{+}\right) .[\alpha]_{\mathrm{D}}^{293}+5.7\left(c\right.$ 1.0, $\left.\mathrm{CHCl}_{3}\right)$.

\subsubsection{Compound 2-urea}

Compound 1-urea ( $2.50 \mathrm{~g}, 4.29 \mathrm{mmol}, 1$ equiv) was suspended in $\mathrm{MeOH}(25 \mathrm{~mL})$, and then aqueous $\mathrm{NaOH}$ ( $15 \mathrm{~mL}, 1 \mathrm{M}, 15 \mathrm{mmol}, 3.5$ equiv) was added. The reaction mixture was stirred for $48 \mathrm{~h}$ under nitrogen. The solvents were removed by rotary evaporation, water $(10 \mathrm{~mL})$ added and then the mixture was acidified to $\mathrm{pH} 3$ with $\mathrm{NaHSO}_{4}$. A white solid resulted that was collected by filtration, washed with water and then dried under high vacuum for $48 \mathrm{~h}$, yielding 2-urea as a white solid (2.0 g, 
$0.34 \mathrm{mmol}, 84 \%) .{ }^{1} \mathrm{H}$ NMR (400 MHz, DMSO) $\delta_{\mathrm{H}} 6.21-5.92(2 \mathrm{H}, \mathrm{br} \mathrm{m}, \mathrm{NH}), 5.78-5.68(2 \mathrm{H}, \mathrm{br} \mathrm{m}, \mathrm{NH}$, $2 \mathrm{H})$, 4.09-4.01 (1H, m, COCH(R)NH), 3.39-3.31 (2H, m, L-Lys- $\mathrm{CH}_{2} \mathrm{NH}$, obscured), 2.96-2.89 (4H, m, $\left.\mathrm{NHCH}_{2} \mathrm{C}_{11} \mathrm{H}_{23}\right), 1.56-1.15\left(46 \mathrm{H}, \mathrm{m}, \mathrm{CH}_{2}\right), 0.85-0.80\left(6 \mathrm{H}, \mathrm{t}, \mathrm{J}=6.8 \mathrm{~Hz}, \mathrm{CH}_{3}\right) .{ }^{13} \mathrm{C} \mathrm{NMR}(100 \mathrm{MHz}, \mathrm{DMSO}) \delta_{\mathrm{C}}$ $173.38\left(\mathrm{CO}_{2} \mathrm{H}\right), 159.62,158.55(\mathrm{CONH}), 52.47(\mathrm{COCH}(\mathrm{R}) \mathrm{NH}), 51.74\left(\mathrm{COCH}_{3}\right), 31.66,29.86,29.39,29.17$, 29.11, 26.66, $22.42\left(\right.$ all $\left.\mathrm{CH}_{2}\right), 14.78\left(\mathrm{CH}_{3} \times 2\right)$, DMSO solvent peak obscures $\mathrm{CH}_{2} \mathrm{NH}$ at ca. $40 \mathrm{ppm}$. IR $(\mathrm{KBr}$ disc) $V_{\max } \mathrm{cm}^{-1} 3342(\mathrm{NH}), 1684$ (C<img border="0" alt="double bond; length as $\mathrm{m}$-dash" src="http://cdn.els-cdn.com/sd/entities/dbnd" class="glyphlmg">0, carboxylic acid), 1655 (C<img border="0" alt="double bond; length as m-dash" src="http://cdn.els-cdn.com/sd/entities/dbnd" class="glyphImg">O, urea), $1535(\mathrm{CONH})$. ESI-MS (m/z) calculated value for $\mathrm{C}_{33} \mathrm{H}_{66} \mathrm{~N}_{4} \mathrm{O}_{4}$ [M] requires: 568.5; $\left(\mathrm{ES}^{+}\right)$found: $591.5\left(100 \%,[\mathrm{M}+\mathrm{Na}]^{+}\right) .[\alpha]_{D}^{293}-2.1$ (c 1.0, $\left.\mathrm{CHCl}_{3}\right)$.

\subsubsection{Compound 1-diacylhydrazine}

Dodecanoichydrazide (5.00 g, $25 \mathrm{mmol}, 2.05$ equiv) was added to a solution of methyl 2,6diisocyanatohexanoate (LDI) (2.59 g, $2.24 \mathrm{~mL}, 12.2 \mathrm{mmol}, 1$ equiv) in toluene (100 mL). The solution was stirred for $16 \mathrm{~h}$ at $100{ }^{\circ} \mathrm{C}$, after which time, the volatiles were removed by rotary evaporation. Two recrystallisations from methanol-diethyl ether (100 mL, 1:1) and subsequent filtration, followed by $24 \mathrm{~h}$ under high vacuum resulted in compound 1-diacylhydrazine as a white solid in quantitative yield (7.81 g, $12.2 \mathrm{mmol}) .{ }^{1} \mathrm{H}$ NMR (400 MHz, DMSO) $\delta_{\mathrm{H}} 9.46(1 \mathrm{H}, \mathrm{s}, \mathrm{CONHNHCO}), 9.37(1 \mathrm{H}, \mathrm{s}$, CONHNHCO), $7.84(1 \mathrm{H}, \mathrm{s}, \mathrm{CONHNHCO}), 7.61(1 \mathrm{H}, \mathrm{s}, \mathrm{CONHNHCO}), 6.55(1 \mathrm{H}, \mathrm{d}, \mathrm{J}=7.8 \mathrm{~Hz}, \mathrm{NH}), 6.26-$ $6.20(1 \mathrm{H}, \mathrm{br} \mathrm{m}, \mathrm{NH}), 4.13-4.07(1 \mathrm{H}, \mathrm{m}, \mathrm{COCH}(\mathrm{R}) \mathrm{NH}), 3.60\left(3 \mathrm{H}, \mathrm{s}, \mathrm{CO}_{2} \mathrm{CH}_{3}\right), 3.01-2.86(2 \mathrm{H}, \mathrm{m}, \mathrm{L}-\mathrm{Lys}-$ $\left.\mathrm{CH}_{2} \mathrm{NH}\right), 2.06-1.98\left(4 \mathrm{H}, \mathrm{br} \mathrm{m}, \mathrm{COCH}_{2} \mathrm{C}_{11} \mathrm{H}_{23}\right), 1.67-1.02\left(46 \mathrm{H}, \mathrm{m}, \mathrm{CH}_{2}\right), 0.85-0.75\left(6 \mathrm{H}, \mathrm{t}, \mathrm{J}=6.8 \mathrm{~Hz}, \mathrm{CH}_{3}\right)$. ${ }^{13} \mathrm{C} N M R(100 \mathrm{MHz}, \mathrm{DMSO}) \delta_{\mathrm{C}} 174.23\left(\mathrm{CO}_{2} \mathrm{Me}\right), 159.64,158.45(\mathrm{CONH}), 52.17(\mathrm{COCH}(\mathrm{R}) \mathrm{NH}), 51.79$ ( $\mathrm{COOCH}_{3}$ ), 39.65, 31.65, 29.79, 29.39, 29.28, 29.09, 25.13, 22.42 (all $\left.\mathrm{CH}_{2}\right), 13.77\left(\mathrm{CH}_{3} \times 2\right)$. IR ( $\mathrm{KBr}$ disc) $V_{\max } \mathrm{cm}^{-1} 3351(\mathrm{NH}), 1724$ (C<img border="0" alt="double bond; length as m-dash" src="http://cdn.els-cdn.com/sd/entities/dbnd" class="glyphlmg">0, ester), 1630 (C<img border="0" alt="double bond; length as m-dash" src="http://cdn.els-cdn.com/sd/entities/dbnd" class="glyphImg">O, urea/amide), $1540(\mathrm{CONH})$. ESI-MS $(\mathrm{m} / \mathrm{z})$ calculated value for $\mathrm{C}_{33} \mathrm{H}_{64} \mathrm{~N}_{6} \mathrm{O}_{6}[\mathrm{M}]$ requires: 640.5; $\left(\mathrm{ES}^{+}\right)$found: $663\left(100 \%,[\mathrm{M}+\mathrm{Na}]^{+}\right)$. HR-FAB $(\mathrm{m} / \mathrm{z}) \mathrm{C}_{33} \mathrm{H}_{64} \mathrm{~N}_{6} \mathrm{O}_{6} \mathrm{Na}[\mathrm{M}]^{+}$calculated: 663.4785; found 663.4790. $[\alpha]_{D}{ }^{293}-85.2\left(c 1.0, \mathrm{CHCl}_{3}\right)$.

\subsubsection{Compound 2-diacylhydrazine}

Compound 1-diacylhydrazine ( $2.50 \mathrm{~g}, 3.9 \mathrm{mmol}, 1$ equiv) was suspended in $\mathrm{MeOH}(25 \mathrm{~mL})$. Then aqueous $\mathrm{NaOH}$ ( $15 \mathrm{~mL}, 1 \mathrm{M}, 15 \mathrm{mmol}, 3.5$ equiv) was added. The reaction mixture was stirred for $48 \mathrm{~h}$ under nitrogen. The solvents were removed by rotary evaporation, water $(10 \mathrm{~mL})$ added and then the mixture was acidified to $\mathrm{pH} 3$ with $\mathrm{NaHSO}_{4}$. A white solid resulted that was collected by filtration, washed with water and then dried under high vacuum for $48 \mathrm{~h}$, yielding the desired product $(2.00 \mathrm{~g}$, $0.32 \mathrm{mmol}, 82 \%) .{ }^{1} \mathrm{H}$ NMR (400 MHz, DMSO) $\delta_{\mathrm{H}} 9.45-9.38(2 \mathrm{H}, \mathrm{br} \mathrm{m}, \mathrm{NH}), 7.83-7.77(2 \mathrm{H}, \mathrm{br} \mathrm{m}, \mathrm{NH})$, 
6.42-6.39 (2H, br m, NH), 4.04-4.00 (1H, m, COCH(R)NH), 2.92-2.90 (2H, m, L-Lys-CH $\left.{ }_{2} N H\right), 2.01-1.98$ $\left(4 \mathrm{H}, \mathrm{br} \mathrm{m}, \mathrm{COCH}_{2} \mathrm{C}_{11} \mathrm{H}_{23}\right), 1.71-0.98\left(46 \mathrm{H}, \mathrm{m}, \mathrm{CH}_{2}\right), 0.85-0.75\left(6 \mathrm{H}, \mathrm{t}, \mathrm{J}=6.8 \mathrm{~Hz}, \mathrm{CH}_{3}\right) .{ }^{13} \mathrm{C} \mathrm{NMR}(100 \mathrm{MHz}$, DMSO) $\delta_{\mathrm{C}} 173.31\left(\mathrm{CO}_{2} \mathrm{H}\right), 155.76$ (CONH overlapping), $52.17(\mathrm{COCH}(\mathrm{R}) \mathrm{NH}), 31.68,29.99,29.42,29.28$, 29.09, 25.13, 22.41 (all $\left.\mathrm{CH}_{2}\right), 14.14\left(\mathrm{CH}_{3} \times 2\right)$, DMSO solvent peak obscures $\mathrm{CH}_{2} \mathrm{NH}$ at ca. $40 \mathrm{ppm}$. IR $(\mathrm{KBr}$ disc) $v_{\max } \mathrm{cm}^{-1} 3351(\mathrm{NH}), 1684$ (C<img border="0" alt="double bond; length as m-dash" src="http://cdn.els-cdn.com/sd/entities/dbnd" class="glyphlmg">0, carboxylic acid), 1630 (C<img border="0" alt="double bond; length as m-dash" src="http://cdn.els-cdn.com/sd/entities/dbnd" class="glyphImg">O, amide/urea), 1541 (CONH). ESI-MS (m/z) calculated value for $\mathrm{C}_{32} \mathrm{H}_{62} \mathrm{~N}_{6} \mathrm{O}_{6}[\mathrm{M}]$ requires: 626.5; $\left(\mathrm{ES}^{+}\right)$found: $649.5\left(100 \%,[\mathrm{M}+\mathrm{Na}]^{+}\right)$. $[\alpha]_{\mathrm{D}}^{293}-79.6\left(c\right.$ 1.0, $\left.\mathrm{CHCl}_{3}\right)$.

\subsubsection{Compound 1-thiourea}

$N$-Dodecylisothiocyanate $(0.50 \mathrm{~g}, 2.19 \mathrm{mmol}, 2.0$ equiv) was added to a solution of L-lysine methyl ester dihydrochloride $(0.26 \mathrm{~g}, 1.09 \mathrm{mmol}, 1.0$ equiv) and triethylamine $(0.276 \mathrm{~g}, 0.38 \mathrm{~mL}, 2.73 \mathrm{mmol}$, 2.5 equiv) in toluene $(10 \mathrm{~mL})$. The solution was stirred for $16 \mathrm{~h}$ at $100^{\circ} \mathrm{C}$. After cooling and subsequent removal of the solids, the solvent was removed by rotary evaporation. Two recrystallisations from methanol-diethyl ether ( $10 \mathrm{~mL}, 1: 1)$ and subsequent filtration, followed by $24 \mathrm{~h}$ under high vacuum resulted in an off-white solid in $72 \%$ yield $(0.49 \mathrm{~g}, 0.79 \mathrm{mmol}) .{ }^{1} \mathrm{H}$ NMR $\left(400 \mathrm{MHz}\right.$, DMSO) $\delta_{\mathrm{H}} 7.33-7.21$ $(4 \mathrm{H}, \mathrm{br} \mathrm{m}, \mathrm{NH}), 4.20-4.18(1 \mathrm{H}, \mathrm{m}, \mathrm{COCH}(\mathrm{R}) \mathrm{NH}), 3.59-3.55\left(3 \mathrm{H}, \mathrm{s}, \mathrm{CO}_{2} \mathrm{CH}_{3}\right), 3.52-3.23(2 \mathrm{H}, \mathrm{br} \mathrm{m}, \mathrm{L}-\mathrm{Lys}-$ $\mathrm{CH}_{2} \mathrm{NH}$, obscured), 2.47-2.42 (4H, br m, $\left.\mathrm{NHCH}_{2} \mathrm{C}_{11} \mathrm{H}_{23}\right), 1.71-1.05\left(46 \mathrm{H}, \mathrm{m}, \mathrm{CH}_{2}\right), 0.81-0.77(6 \mathrm{H}, \mathrm{t}$, $\left.J=6.8 \mathrm{~Hz}, \mathrm{CH}_{3}\right) .{ }^{13} \mathrm{C} \mathrm{NMR}(100 \mathrm{MHz}, \mathrm{DMSO}) ; \delta_{\mathrm{C}} 174.26\left(\mathrm{CO}_{2} \mathrm{Me}\right), 139.64,132.11$ (C=S), 52.38 $(\mathrm{COCH}(\mathrm{R}) \mathrm{NH}), 51.79\left(\mathrm{COOCH}_{3}\right), 30.26,29.95,29.39,28.39,26.66,23.22,23.17$ (all $\left.\mathrm{CH}_{2}\right), 14.79\left(\mathrm{CH}_{3} \times 2\right)$, DMSO solvent peak obscures $\mathrm{CH}_{2} \mathrm{NH}$ at ca. $40 \mathrm{ppm}$. IR ( $\mathrm{KBr}$ disc) $v_{\max } \mathrm{cm}^{-1} 3332(\mathrm{NH}), 1742$ (C<img border="0" alt="double bond; length as m-dash" src="http://cdn.els-cdn.com/sd/entities/dbnd" class="glyphlmg">0, ester), 1229 (C<img border="0" alt="double bond; length as $\mathrm{m}$-dash" src="http://cdn.els-cdn.com/sd/entities/dbnd" class="glyphlmg">S, thiourea). ESI-MS (m/z) calculated value for $\mathrm{C}_{33} \mathrm{H}_{66} \mathrm{~N}_{4} \mathrm{O}_{2} \mathrm{~S}_{2}[\mathrm{M}]$ requires: 614.5; $\left(\mathrm{ES}^{+}\right)$found: $615.5\left(100 \%,[\mathrm{M}+\mathrm{H}]^{+}\right)$. $[\alpha]_{\mathrm{D}}{ }^{293}-0.2$ (c 1.0, $\mathrm{CHCl}_{3}$ ).

\subsubsection{Compound 2-thiourea}

Compound 1-thiourea ( $0.25 \mathrm{~g}, 0.40 \mathrm{mmol}, 1$ equiv) was suspended in $\mathrm{MeOH}$ ( $25 \mathrm{~mL}$ ). Then aqueous $\mathrm{NaOH}$ (1.2 mL, $1 \mathrm{M}, 1.2 \mathrm{mmol}, 3$ equiv) was added. The reaction mixture was stirred for $48 \mathrm{~h}$ under nitrogen. The solvent was removed by rotary evaporation, water $(10 \mathrm{~mL})$ added and then the mixture was acidified to $\mathrm{pH} 3$ with $\mathrm{NaHSO}_{4}$. An off-white solid resulted was collected by filtration, washed with water and then dried under high vacuum for $48 \mathrm{~h}$, yielding the desired product $(0.20 \mathrm{~g}, 0.34 \mathrm{mmol}$, 84\%). ${ }^{1} \mathrm{H}$ NMR (400 MHz, DMSO) $\delta_{\mathrm{H}} 7.34-7.22(4 \mathrm{H}, \mathrm{br} \mathrm{m}, \mathrm{NH}), 4.20-4.18(1 \mathrm{H}, \mathrm{m}, \mathrm{COCH}(\mathrm{R}) \mathrm{NH}), 3.52-$ $3.23\left(2 \mathrm{H}\right.$, br m, L-Lys- $\mathrm{CH}_{2} \mathrm{NH}$, obscured), 2.47-2.41 (4H, br m, $\left.\mathrm{NHCH}_{2} \mathrm{C}_{11} \mathrm{H}_{23}\right), 1.73-1.02\left(46 \mathrm{H}, \mathrm{m}, \mathrm{CH}_{2}\right)$, $0.81-0.77\left(6 \mathrm{H}, \mathrm{t}, \mathrm{J}=6.8 \mathrm{~Hz}, \mathrm{CH}_{3}\right) .{ }^{13} \mathrm{C}$ NMR $(100 \mathrm{MHz}, \mathrm{DMSO}) ; \delta_{\mathrm{c}} 173.78\left(\mathrm{CO}_{2} \mathrm{H}\right), 139.63,132.21(\mathrm{C}<\mathrm{img}$ 
border="0" alt="double bond; length as m-dash" src="http://cdn.els-cdn.com/sd/entities/dbnd" class="glyphlmg">S), 52.39 ( $\mathrm{COCH}(\mathrm{R}) \mathrm{NH}), 30.26,29.98,29.34,28.39,26.66,23.22,23.17$ (all $\mathrm{CH}_{2}$ ), $14.79\left(\mathrm{CH}_{3} \times 2\right)$, DMSO solvent peak obscures $\mathrm{CH}_{2} \mathrm{NH}$ at ca. $40 \mathrm{ppm}$. IR ( $\left.\mathrm{KBr} \operatorname{disc}\right) v_{\max } \mathrm{cm}^{-1} 3332(\mathrm{NH})$, 1685 (C<img border="0" alt="double bond; length as m-dash" src="http://cdn.elscdn.com/sd/entities/dbnd" class="glyphlmg">0, carboxylic acid), 1215 (C<img border="0" alt="double bond; length as m-dash" src="http://cdn.els-cdn.com/sd/entities/dbnd" class="glyphImg">S, thiourea). ESI-MS $(\mathrm{m} / \mathrm{z})$ calculated value for $\mathrm{C}_{32} \mathrm{H}_{64} \mathrm{~N}_{4} \mathrm{O}_{2} \mathrm{~S}_{2}$ [M] requires: 600.5; (ES $\left.{ }^{-}\right)$found: $599.5\left(100 \%,[\mathrm{M}-\mathrm{H}]^{-}\right)$. $[\alpha]_{\mathrm{D}}{ }^{293}-0.2\left(c \mathrm{c} 1.0, \mathrm{CHCl}_{3}\right)$.

\subsection{Methods for studying gels}

\subsubsection{Thermal studies}

These experiments were performed by solubilisation of a weighed amount of gelator in a measured volume of selected pure solvent. The mixture was sonicated at ambient temperature for $30 \mathrm{~min}$ before heating and cooling produced a gel. The gel sample was left to stand overnight. Gelation was considered to have occurred when a homogeneous 'solid-like' material was obtained that exhibited no gravitational flow. The thermally reversible gel-sol transition temperature $\left(T_{\text {gel }}\right)$ was determined by using a tube-inversion methodology. The gel-sol transition temperature represents the point at which the stress exerted by the gel exceeds its yield strength and a drop of solvent begins to run from the immobilised gel. All samples of gel-phase materials were prepared with a total volume of $1 \mathrm{~mL}$ in tubes with a diameter of $10 \mathrm{~mm}$. This ensures that the stress generated by the gel on tube inversion is approximately constant in each case.

\subsubsection{Fourier transform infrared (FTIR) studies}

FTIR spectroscopy was performed on gels formed in selected pure solvents operating at a $1 \mathrm{~cm}^{-1}$ resolution with 32 scans. A spectroscopic cell with $\mathrm{NaCl}$ windows and $100 \mu \mathrm{m}$ spacers was used for the measurements.

\subsubsection{Field emission gun scanning electron microscopy (FEG-SEM)}

Gel samples were applied to standard aluminium SEM stubs and allowed to dry. Prior to examination, the gels were coated with a thin layer $(5 \mathrm{~nm})$ of $\mathrm{Pd} / \mathrm{Pt}$ using an Agar high-resolution sputter coater fitted with a thickness monitor/controller. Scanning electron micrographs were recorded by using a LEO 1530 Gemini FEG-SEM instrument operated at $3 \mathrm{keV}$. The images were obtained by John Harrington at LEMAS (University of Leeds).

\subsubsection{Circular dichroism (CD) spectroscopy}


CD spectra were recorded in the ultraviolet region $(200-350 \mathrm{~nm})$ by using a JASCO 810 spectrometer and a $1.0 \mathrm{~mm}$ quartz cuvette. A sample interval of $1 \mathrm{~nm}$ and an averaging time of $3 \mathrm{~s}$ were used in all experiments. [Gelator] $=3 \mathrm{~mm}$.

Acknowledgements

We thank EPSRC (C/520750/1) and Syngenta for providing financial support for this research.

References and notes

1

(a) G.M. Whitesides

Small, 1 (2005), p. 172

(b) D.K. Smith, A.R. Hirst, C.S. Love, J.G. Hardy, S.V. Brignell, B. Huang

Prog. Polym. Sci., 30 (2005), pp. 220-293

2

(a) P. Terech, R.G. Weiss

Chem. Rev., 97 (1997), pp. 3133-3159

(b) O. Gronwald, E. Snip, S. Shinkai

Curr. Opin. Colloid Interfac Sci., 7 (2002), pp. 148-156

(c) N. Sangeetha, U. Maitra

Chem. Soc. Rev., 34 (2005), pp. 821-836

3

D.J. Selkoe

Nature, 426 (2003), pp. 900-904 
P.D. Beer, P.A. Gale, D.K. Smith

\section{Supramolecular Chemistry}

Oxford University Press, Oxford (1999)

5

R. Luboradzki, O. Gronwald, M. Ikeda, S. Shinkai, D.N. Reinhoudt

e.g. Tetrahedron, 56 (2000), pp. 9595-9599

6

F. Fages, F. Vögtle, M. Žinić

Top. Curr. Chem., 256 (2005), pp. 77-131

7

K. Araki, I. Yoshikawa

Top. Curr. Chem., 256 (2005), pp. 133-165

8

M. Žinić, F. Vögtle, F. Fages

Top. Curr. Chem., 256 (2005), pp. 39-76

9

(a) Y. Ono, K. Nakashima, M. Sano, Y. Kanekiyo, K. Inoue, J. Hojo, S. Shinkai

Chem. Commun. (1998), pp. 1477-1478

(b) J.H. Jung, Y. Ono, S. Shinkai

Angew. Chem., Int. Ed., 39 (2000), pp. 1862-1865

(c) E.D. Sone, E.R. Zubarev, S.I. Stupp

Angew. Chem., Int. Ed., 41 (2002), pp. 1705-1709 
(d) C.L. Chan, J.B. Wang, J. Yuan, H. Gong, Y.H. Liu, M.H. Liu Langmuir, 20 (2004), pp. 6470-6475

(e) C.S. Love, V. Chechik, D.K. Smith, K. Wilson, I. Ashworth, C. Brennan

Chem. Commun. (2005), pp. 1971-1973

10

(a) A. Friggeri, B.L. Feringa, J. van Esch

J. Controlled Release, 97 (2004), pp. 241-248

(b) K.J.C. van Bommel, M.C.A. Stuart, B.L. Feringa, J. van Esch

Org. Biomol. Chem., 3 (2005), pp. 2917-2920

(c) P.K. Vemula, J. Li, G. John

J. Am. Chem. Soc., 128 (2006), pp. 8932-8938

(d) R. Karinaga, Y. Jeong, S. Shinkai, K. Kaneko, K. Sakurai

Langmuir, 21 (2005), pp. 9398-9401

11

R.G. Ellis-Behnke, Y.X. Liang, S.W. You, D.K.C. Tay, S.G. Zhang, K.F. So, G.E. Schneider Proc. Natl. Acad. Sci. U.S.A., 103 (2006), pp. 5054-5059

12

A. Aggeli, I.A. Nyrkova, M. Bell, R. Harding, L. Carrick, T.C.B. McLeish

Proc. Natl. Acad. Sci. U.S.A., 98 (2001), pp. 11857-11862

13

(a) A.R. Hirst, D.K. Smith, M.C. Feiters, H.P.M. Geurts

Langmuir, 20 (2004), pp. 7070-7077 
(b) B. Escuder, M. LLusar, J.F. Miravet

J. Org. Chem., 71 (2006), pp. 7747-7752

14

D.K. Smith

Chem. Commun. (2006), pp. 34-44

15

(a) K.S. Partridge, D.K. Smith, G.M. Dykes, P.T. McGrail

Chem. Commun. (2001), pp. 319-320

(b) C.S. Love, A.R. Hirst, V. Chechik, D.K. Smith, I. Ashworth, C. Brennan Langmuir, 20 (2004), pp. 6580-6585

(c) B. Huang, A.R. Hirst, D.K. Smith, V. Castelletto, I.W. Hamley

J. Am. Chem. Soc., 127 (2005), pp. 7130-7139

16

A.R. Hirst, D.K. Smith

Org. Biomol. Chem., 2 (2004), pp. 2965-2971

17

A.R. Hirst, D.K. Smith, M.C. Feiters, H.P.M. Geurts

Chem.-Eur. J., 10 (2004), pp. 5901-5910

18

A.R. Hirst, D.K. Smith

Langmuir, 20 (2004), pp. 10851-10857 
(a) A.R. Hirst, D.K. Smith, M.C. Feiters, H.P.M. Geurts, A.C. Wright

J. Am. Chem. Soc., 125 (2003), pp. 9010-9011

(b) A.R. Hirst, D.K. Smith, J.P. Harrington

Chem.-Eur. J., 11 (2005), pp. 6552-6559

20

(a) J.-H. Fuhrhop, J. König

Membranes and Molecular Assemblies: the Synkinetic Approach

Royal Society of Chemistry, Cambridge (1994)

(b) K. Hanabusa, K. Okui, K. Karaki, M. Kimura, H. Shirai

J. Colloid Interface Sci., 195 (1997), pp. 86-93

(c) S. Bhattacharya, S.N. Ganashyam Acharya

Chem. Mater., 11 (1999), pp. 3121-3132

(d) A.-C. Couffin-Hoarau, A. Motulsky, P. Delmas, J.C. Leroux

Pharm. Res., 21 (2004), pp. 454-457

(e) X. Luo, B. Liu, Y. Liang

Chem. Commun. (2001), pp. 1556-1557

(f) S. Bhattacharya, Y. Krishnan-Ghosh

Chem. Commun. (2001), pp. 185-186

(g) C. Boettcher, B. Schade, J.-H. Fuhrhop

Langmuir, 17 (2001), pp. 873-877

(h) K. Hanabusa, H. Nakayama, M. Kimura, H. Shirai

Chem. Lett. (2000), pp. 1070-1071 
(i) M. Suzuki, M. Yumoto, M. Kimura, H. Shirai, K. Hanabusa

Chem. Commun. (2002), pp. 884-885

(j) M. Suzuki, M. Yumoto, M. Kimura, H. Shirai, K. Hanabusa

Chem.-Eur. J., 9 (2003), pp. 348-354

(k) M. Suzuki, M. Yumoto, M. Kimura, H. Shirai, K. Hanabusa

New J. Chem., 26 (2002), pp. 817-818

(I) K. Hanabusa, J. Tange, Y. Taguchi, T. Koyama, H. Shirai

J. Chem. Soc., Chem. Commun. (1993), pp. 390-392

(m) K. Hanabusa, A. Itoh, M. Kimura, H. Shirai

Chem. Lett. (1999), pp. 1077-1078

(n) N. Nakashima, S. Asakuma, T. Kunitake

J. Am. Chem. Soc., 107 (1985), pp. 509-510

(o) J.-H. Fuhrhop, D. Spiroski, C. Boettcher

J. Am. Chem. Soc., 115 (1993), pp. 1600-1601

(p) H. Ihara, H. Hachisako, C. Hirayama, K. Zamada

J. Chem. Soc., Chem. Commun. (1992), pp. 1244-1245

(q) A. Heeres, C. van der Pol, M. Stuart, A. Friggeri, B.L. Feringa, J. van Esch

J. Am. Chem. Soc., 125 (2003), pp. 14252-14253

(r) K.J.C. van Bommel, C. van der Pol, I. Muizebelt, A. Friggeri, A. Heeres, A. Metsma, B.L. Feringa, J. van Esch

Angew. Chem., Int. Ed., 43 (2004), pp. 1663-1667

(s) E.J. de Vries, R. Kellogg 
J. Chem. Soc., Chem. Commun. (1993), pp. 238-240

21

J.G. Hardy, A.R. Hirst, D.K. Smith, C. Brennan, I. Ashworth

Chem. Commun. (2005), pp. 385-387

22

M. Suzuki, M. Yumoto, M. Kimura, H. Shirai, K. Hanabusa

Helv. Chim. Acta, 87 (2004), pp. 1-10

23

(a) M. Suzuki, Y. Nakajima, M. Yumoto, M. Kimura, H. Shirai, K. Hanabusa

Org. Biomol. Chem., 2 (2004), pp. 1155-1159

(b) A.J. Carr, R. Melendez, S.J. Geib, A.D. Hamilton

Tetrahedron Lett., 39 (1998), pp. 7447-7450

(c) L.A. Estroff, L. Leiserowitz, L. Addadi, S. Weiner, A.D. Hamilton Adv. Mater., 15 (2003), pp. 38-42

(d) J. Brinksma, B.L. Feringa, R.M. Kellogg, R. Vreeker, J. van Esch Langmuir, 16 (2000), pp. 9249-9255

24

P. Jonkheijm, P. van der Schoot, A.P.H.J. Schenning, E.W. Meijer

Science, 313 (2006), pp. 80-83

25

R.M. Silverstein, G.C. Bassler, T.C. Morrill

Spectrometric Identification of Organic Compounds 
(6th ed.)John Wiley and Sons, New York, NY (1997)

26

S. Nishizawa, P. Buhlmann, M. Iwao, Y. Umezawa

Tetrahedron Lett., 36 (1995), pp. 6483-6486

27

N. Berova, K. Nakanishi, R.W. Woody (Eds.), Circular Dichroism. Principles and Applications, Wiley-VCH, New York, NY (2000)

28

S.M. Kelly, N.C. Price

Curr. Protein Pept. Sci., 1 (2000), pp. 349-384

29

A.R. Hirst, D.K. Smith

For a review see: Chem.-Eur. J., 11 (2005), pp. 5496-5508

30

B. Anand, S.S. Pisal, A.R. Paradkar, K.R. Mahadik

J. Sci. Ind. Res., 60 (2001), pp. 311-318

31

C.E. Davies, T.D. Heightman, S.A. Hermitage, M.G. Moloney

Synth. Commun., 26 (1996), pp. 687-696

Corresponding author. Tel.: +44 1904 434181; fax: +44 1904434523. 